\title{
RELAÇÃO ENTRE ESPAÇOS URBANOS E ESPAÇOS FLUVIAIS: CONFLITOS E INTERAÇÕES EM IPABA (MG), NO VALE DO RIO DOCE
}

\author{
RELATIONSHIP BETWEEN URBAN SPACES AND FLUVIAL SPACES: \\ CONFLICTS AND INTERACTIONS IN IPABA (MG), IN THE RIO DOCE VALLEY
}

Rômulo Croce

Eneida Maria Souza Mendonça

\begin{abstract}
Resumo
O trabalho possui como objetivo principal analisar a relação entre espaço urbano e espaço fluvial no município de Ipaba (MG), que está inserido ao longo do Vale do Rio Doce. O município mineiro também está inserido na periferia geográfica, social e econômica da Região Metropolitana do Vale do Aço, que consiste em uma aglomeração de municípios extremamente dinâmica do ponto de vista socioeconômico, abrigando infraestruturas e plantas industriais responsáveis por (re)modelar a dinâmica de ocupação territorial da região, incluindo os espaços lindeiros ao rio Doce. A metodologia consistiu em revisão bibliográfica sobre o tema e na aplicação de método desenvolvido por Souza (2015), para análise do espaço fluvial. Foi observado que as margens, no município, são totalmente privatizadas, ocupadas por áreas agrícolas e desarticuladas do tecido urbano. Além disso, observa-se que o rompimento da barragem de rejeitos da Samarco (Vale/BHP Billiton), trouxe expressivos impactos sociais e territoriais para o local, que, somados a uma legislação ineficiente, e ao vetor de crescimento do município, em sentido oposto ao rio, podem resultar em distanciamento de laços afetivos da população para com o rio.
\end{abstract}

Palavras-Chave: Margens Fluviais. Urbanização. Rio Doce. Espaços livres. Região Metropolitana do Vale do Aço.

\begin{abstract}
The main objective of this paper is to analyze the relationship between urban space and river space in the municipality of Ipaba (MG), which is inserted along the Rio Doce Valley. The municipality of Minas Gerais is also inserted in the geographic, social and economic periphery of the Metropolitan Region of Vale do Aço, which consists of an extremely dynamic agglomeration of municipalities from a socioeconomic point of view, housing infrastructures and industrial plants responsible for (re) modeling the dynamics of territorial occupation of the region, including the areas bordering the Doce river. The methodology consisted of a bibliographic review on the theme and the application of a method developed by Souza (2015), for the analysis of the river space. It was observed that the banks, in the municipality, are totally privatized, occupied by agricultural areas and disjointed from the urban fabric. Furthermore, it is observed that the rupture of the Samarco tailings dam (Vale/HP Billiton), brought significant social and territorial impacts to the place, which, added to inefficient legislation, and to the municipality's growth vector, opposite to the river, may result in a distance from the population's affective ties to the river.
\end{abstract}

Keywords: River Banks. Urbanization. Doce River. Open Spaces. Metropolitan Region of Vale do Aço. 


\section{IntRodução}

A problemática abordada se ancora na constatação de que o processo de urbanização ocorrido em cidades brasileiras contribuiu para o distanciamento dessas com seus cursos d'água, favorecendo a descaracterização paisagística e ambiental, além da perda desses elementos enquanto referenciais históricos, culturais e estéticos (COSTA, L. 2006). O estudo busca analisar o espaço entre o rio e a cidade, também denominado de espaço fluvial urbano, partindo do princípio de que uma relação mais harmônica entre ambos é capaz de trazer benefícios de ordem ambiental e social. Parte do pressuposto de que a compreensão dos espaços fluviais como parte intrínseca do Sistema de Espaços Livres (SEL) urbanos é fundamental para o desenvolvimento de estratégias para sua qualificação social e paisagística.

O presente trabalho deriva de um estudo mais amplo, que busca compreender essa conflituosa relação em escala de bacia hidrográfica, corroborando autores como Mello (2008), Lucia Costa (2006) e com o próprio Plano Nacional de Recursos Hídricos (BRASIL, 1997), e que tem como objeto de estudo as margens do rio Doce, ao longo de sua rede hidrográfica principal.

Apresentam-se, neste artigo, como recorte de estudo, as margens do rio Doce junto à área urbana do município de Ipaba, que está localizado na porção média da bacia do rio Doce e que possui importante relação social, ambiental e cultural com esse rio. A decisão de tratar desse local perpassou por um processo de seleção que levou em consideração os 52 municípios atravessados pelos rios Doce, Carmo e Piranga e os analisou segundo critérios socioeconômicos (CROCE, 2020). Ipaba é caracterizado por abranger reduzida concentração de renda, o pior índice de qualidade de vida do Vale do Rio Doce, além estar inserido em um limiar hierárquico inferior da rede urbana regional, a despeito de localizar-se no colar metropolitano do promissor Vale do Aço (IBGE, 2008; 2016; 2018; FJP, IPEA, PNUD, 2010).

O objetivo principal do trabalho é investigar a relação entre o processo de urbanização e as margens do rio Doce no município de Ipaba, de modo a compreender os conflitos e as interações que permeiam a produção do espaço fluvial. Para tanto, foi realizada uma revisão bibliográfica sobre a posição socioeconômica de Ipaba na bacia do rio Doce, sobre sistemas de espaços livres e espaços fluviais, e, para análise, adotou-se o método desenvolvido por Souza (2015), que consiste em uma análise sistêmica da forma com que a orla fluvial se insere em meio à cidade, relacionando-a com o tecido urbano e com fatores econômicos, sociais e culturais vinculados ao seu processo de produção.

\section{Ipaba e Bacia Hidrográfica do Rio Doce: Uma Breve Contextualização Socioambiental}

A Bacia Hidrográfica do Rio Doce se insere na região Sudeste do Brasil, abrangendo os estados de Minas Gerais e Espírito Santo. A bacia possui grandes proporções, visto que seu território integra dois estados, de acordo com Coelho (2007), com extensão total de $853 \mathrm{~km}$, dos quais 86\% pertencem a Minas Gerais e 14\% ao Espírito Santo e contando com uma área de drenagem de, aproximadamente, $83.465 \mathrm{~km}^{2}$.

O rio Doce, que dá nome à bacia e é seu principal curso d'água, é formado pela confluência dos rios Piranga e do Carmo. O Doce percorre os vales e morros da bacia por uma extensão de $853 \mathrm{~km}$, desde sua nascente até a foz, no Oceano Atlântico, situada na Vila de Regência, no município de Linhares-ES (COELHO, 2019). A bacia conta com um total de 225 municípios que se distribuem entre os dois estados, sendo 200 pertencentes ao território mineiro e 25 ao capixaba. Conta com 209 sedes municipais em seu território e com uma população estimada em 4,1 milhões de habitantes (IBGE, 2018).

A bacia é subdividida em três Unidades Regionais em função das características morfoestruturais encontradas em seu território, sendo elas o Alto, Médio e Baixo Rio Doce (COELHO, 2007).

A Unidade Alto Rio Doce localiza-se a montante da confluência dos rios Doce e Piracicaba. [...] A Unidade Médio Rio Doce possui seus limites à jusante da confluência dos rios Doce e Piracicaba até a divisa dos estados de Minas 
Gerais e Espírito Santo. [...] A Unidade Baixo Rio Doce abrange a porção capixaba (COELHO, 2009. p. 133).

Nesse contexto, o município de Ipaba está inserido na região do Médio Rio Doce, pertencendo à sub-bacia do rio Piracicaba, afluente da margem esquerda do rio Doce (Figura 1). Situa-se na Região Sudeste de Minas Gerais e faz parte do Colar Metropolitano da Região Metropolitana do Vale do Aço (RMVA), estando a cerca de 240 km da capital Belo Horizonte. Sua população estimada para 2019 é de 18.607 habitantes (IBGE,2019) que residem junto ao distrito Sede e ao distrito Vale Verde de Minas.

Sua base econômica é vinculada a atividades de administração, defesa, educação e saúde públicas e seguridade social, tendo também destaque a agricultura, a pecuária extensiva e a extração de madeira (IBGE, 2016), mesmo que não se configurem como os principais meios de arrecadação municipal.

Apesar de não possuir classificação hierárquica definida pelo estudo Região de Influência das Cidades - REGIC (IBGE, 2008), Ipaba conta com características socioeconômicas de um Centro Local ${ }^{1}$. No entanto, sua atuação extrapola os limites municipais, ao contrário do que sugere a publicação do IBGE para centros urbanos com essa característica. Isso ocorre pelo fato de os moradores do distrito de Ipaba do Paraíso (também conhecido como Ipabinha), pertencente ao município de Santana do Paraíso, atravessarem o rio Doce para utilização de equipamentos de Ipaba, como postos de saúde, escolas e demais serviços (CROCE, 2020).

A história de Ipaba está fortemente vinculada ao rio Doce e aos trilhos da Estrada de Ferro Vitória a Minas. Historicamente, o rio representou um importante obstáculo para a expansão do tecido urbano de Ipaba. Nesse caso, porém, ao contrário de outros municípios da bacia, a forma de ultrapassar a barreira de água não se deu por meio de pontes. O movimento pendular de moradores de Ipaba para acessar a outra margem do rio, onde se localiza a estação ferroviária, se dá por meio de botes que, diariamente, fazem o

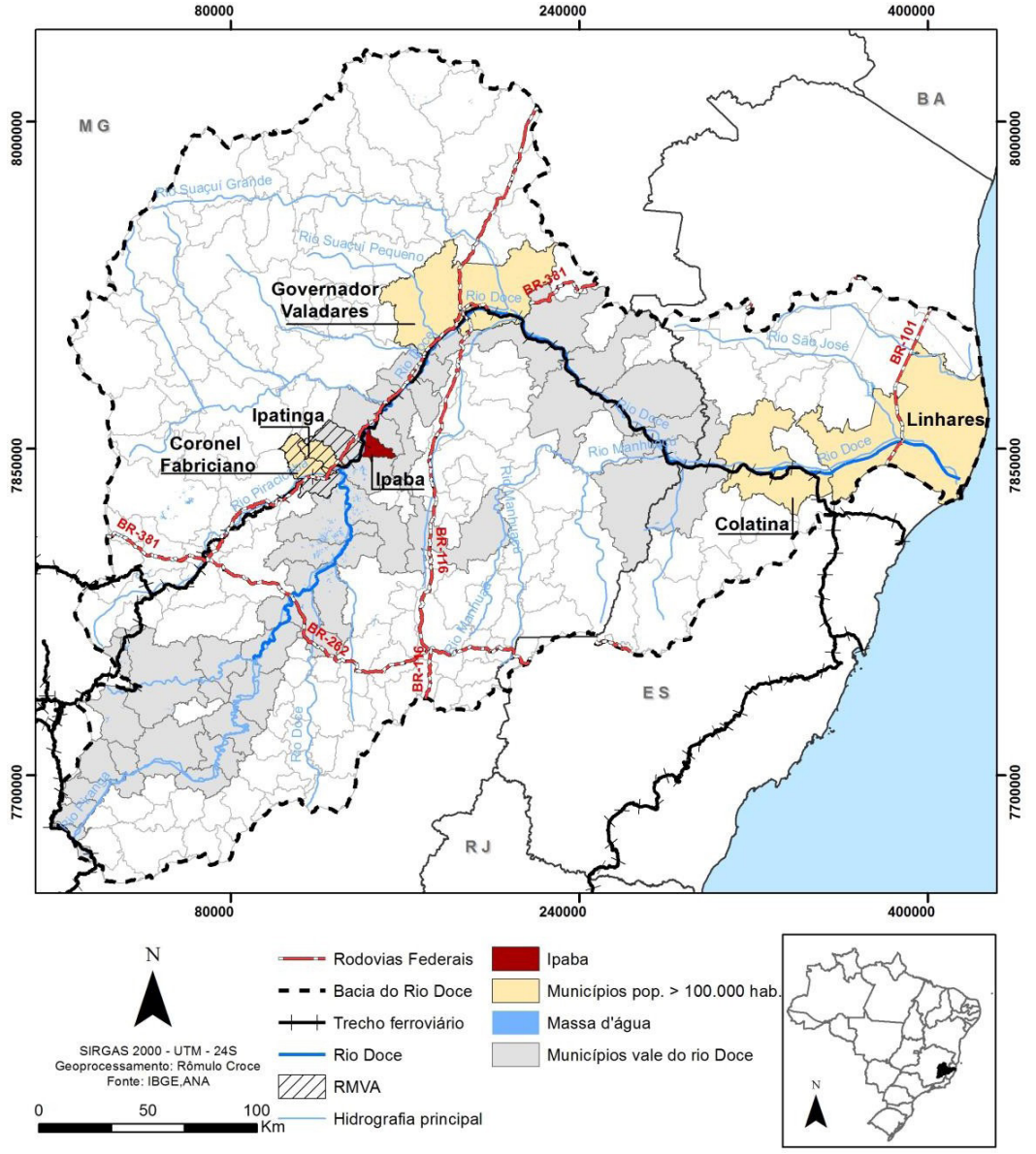

Figura 1 - Localização do município de Ipaba na bacia do rio Doce. Fonte: Elaborado pelos autores, 2019. 
transporte de pessoas. Esse meio de transporte também é fundamental para que os habitantes de Ipaba do Paraíso (Ipabinha) acessem os serviços localizados na outra margem, ou seja, em Ipaba.

É importante destacar que Ipaba está inserido no Colar da única Região Metropolitana da bacia, a Região Metropolitana do Vale do Aço (RMVA). O local, que é composto pelos municípios Ipatinga, Timóteo, Coronel Fabriciano e Santana do Paraíso, teve sua origem ligada ao processo de industrialização da bacia, na década de 1940, com a implantação dos projetos siderúrgicos da Acesita e Usiminas (COSTA, G. e COSTA, H., 2000). A região, que concentra $30 \%$ de toda a população do Vale do Rio Doce (IBGE, 2018), é perpassada por importantes eixos viários regionais, como a rodovia federal BR-116 (Rio-Bahia) e a Estrada de Ferro Vitória a Minas (EFVM), que Ihe conferem posição estratégica e privilegiada em meio ao fluxo de pessoas e mercadorias do país. Atualmente, seu dinamismo econômico e demográfico, além da produção de seu espaço, está fortemente vinculado às atividades industriais presentes em seu território, cuja origem está enraizada no sistema infraestrutural instalado na bacia do rio Doce para extração, beneficiamento e transporte da commodity minério de ferro (ARTE/CIDADE, 2004).

Além disso, em 1975, a introdução da indústria Cenibra, no município de Belo Oriente (Colar Metropolitano), foi responsável por inserir a bacia no mercado internacional de celulose, além de alavancar a prática de silvicultura e induzir significativas transformações socioambientais na porção média do Vale. A implantação dessa indústria também ocasionou transformações territoriais, proporcionadas por suas estratégias corporativas de aquisição de extensos latifúndios para plantio de eucalipto, atingindo, inclusive a região de Ipaba (Figura 2).

A rápida expansão de seu território [os autores se referem ao território produtivo da Cenibra, onde se destacam as áreas de silvicultura] através da compra de propriedades acabou por significar mudanças importantes na lógica produtiva, sendo a sua marca mais importante a transformação de pequenos proprietários em trabalhadores temporários, que muitas vezes migravam para núcleos urbanos ou acampamentos de empresas. A instauração desta nova lógica de produção e trabalho acabou por acelerar as taxas de urbanização nos municípios em que a empresa atuava, em sua maioria na bacia do Rio Doce (FELIPPE et al., 2016, p. 136).

Entretanto, o dinamismo econômico gerado pelo principal polo siderúrgico da América Latina, inserido no Vale do Aço, não abrange a maioria dos municípios do Vale do Rio Doce, sendo notória a desigualdade socioeconômica em seu território. Os municípios caracterizados como principais polos regionais abrigam e acumulam a riqueza da região, bem como boa parte de sua população. A despeito disso, a grande maioria dos seus núcleos urbanos é marcada pela inserção em um limiar inferior da rede hierárquica urbana, com pouca expressividade econômica, decréscimo populacional nas últimas décadas e condições razoáveis de qualidade de vida (IBGE, 2000, 2008, 2016, 2018; FJP, IPEA, PNUD, 2010).

O processo de ocupação da bacia, voltado para o desenvolvimento de atividades altamente impactantes no território, somado às características geográficas do sítio físico em que se instalaram, ocasionou significativos problemas de ordem socioambiental, a saber: o intenso desmatamento oriundo do processo de ocupação urbana e de industrialização; o mau uso do solo, relacionado às extensas áreas de pastagens e ao plantio de eucalipto; a ampla demanda hídrica, sobretudo em sua porção alta e média, para fins industriais ligados à mineração e à siderurgia/celulose; os impactos territoriais oriundos das extensas áreas destinadas à monocultura do eucalipto na porção média; a elevada demanda hídrica para fins agrícolas na porção baixa; os impactos, em comunidades urbanas e tradicionais, oriundos da atividade petrolífera no litoral de Linhares; e os impactos, sobre comunidades urbanas e tradicionais, oriundos das atividades ligadas à mineração na região alta da bacia (PIRH, 2010; FERREIRA, 2016; COELHO, 2009; COELHO, 2019; CROCE, 2020).

Contudo, apesar de não ser recente, nem o processo de extrativismo instalado na bacia e os graves impactos socioambientais gerados pelas atividades que movimentam a economia regional, nem os problemas listados anteriormente se equiparam às consequências advindas do desastre-crime do rompimento da barragem de rejeitos de mineração da Samarco (Vale/BHP Billiton), no subdistrito de 


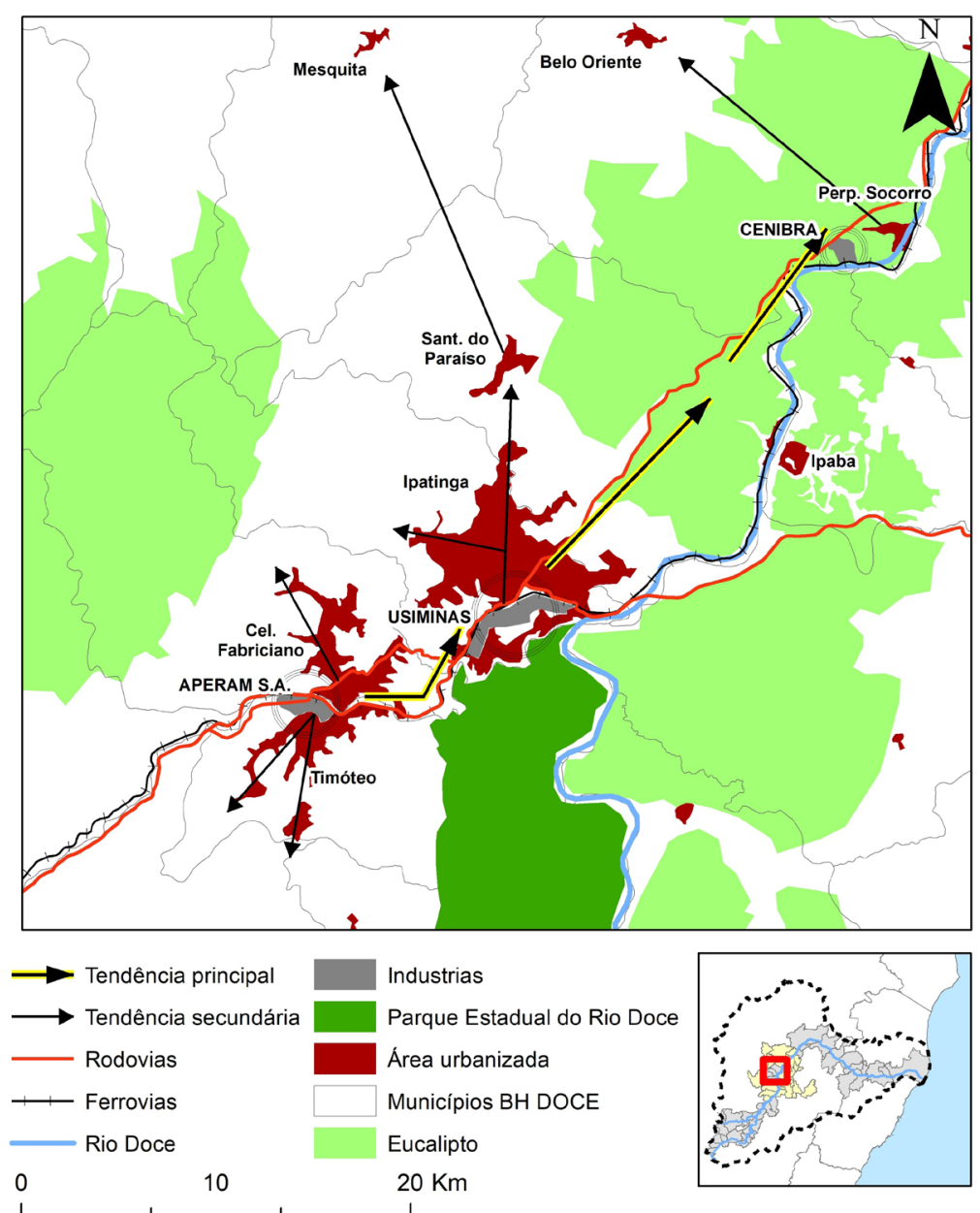

Figura 2 - Mapa dos dispositivos territoriais da monocultura do eucalipto na RMVA. A figura demonstra a espacialização da área destinada ao plantio de eucalipto (verde claro na RMVA, que conforma extensos vazios urbanos. Os vetores urbanos se dão nos locais não ocupados pela silvicultura. Essas localidades estão vinculadas a um complexo de indústrias e a importantes eixos rodoviários, como a EFVM.

Fonte: CROCE, 2020
Bento Rodrigues, município de Mariana, Minas Gerais, sendo esse considerado o maior desastre ambiental da história do Brasil.

O desastre-crime, ocorrido no dia 05 de novembro de 2015, trouxe, para diversos núcleos urbanos, significativos prejuízos socioeconômicos, mas, para as comunidades de quilombolas, indígenas, ribeirinhos, pescadores e demais povoados tradicionais, trouxe a inviabilização de seus modos de viver (FERREIRA, 2016). A onda de rejeitos avançou por $663 \mathrm{~km}$, atingindo rios e córregos (Figura 3), chegando à foz do rio Doce, em Regência, contaminando parte do litoral do Espírito Santo e da Bahia (COELHO, 2019). Foram 19 perdas humanas, aproximadamente 1.200 desabrigados e cerca de 1.500 hectares de terras impactadas, dentre as quais se incluem Áreas Preservação Permanente, Unidades de Conservação e Corredores de Biodiversidade.

No entanto, passados mais de quatro anos do fatídico episódio, a ausência de estratégias claras de recuperação socioambiental por parte do Estado e, principalmente, das empresas envolvidas, é algo que ainda perdura nos dias atuais. $O$ futuro das comunidades atingidas inseridas às margens do rio Doce segue incerto e reforça a necessidade do desenvolvimento de planos urbanos e ambientais mais articulados, em nível de bacia hidrográfica, que visem reestabelecer minimamente o cotidiano da população atingida e a ressignificação social do rio.

Tratando especificamente de Ipaba, as consequências do desastrecrime relatado foram verificadas in loco. Como exemplo, houve relatos de botes que ficaram atracados no rio, tendo passageiros a bordo, devido à espessa lama de rejeitos, que ocasionou danos em seus motores. Levando em consideração a já mencionada importância da travessia do rio pelos botes, houve significativo prejuízo à dinâmica cotidiana, restringindo atividades da população residente nas duas margens.

Reforça-se, com isso, a necessidade do estudo das orlas fluviais e do Sistema de Espaços Livres, pois entende-se que a compreensão dessas questões é de extrema importância para o desenvolvimento de políticas públicas e projetos que prezem por maior qualidade na relação entre cidade e rio. 


\section{O RASTRO DA DESTRUIÇÃO}

O Caminho da Lama... ... na Bacia do Rio Doce

\section{Sistemas de Espaços Livres e Orlas Fluviais}

Nesse artigo, a partir dos conceitos utilizados no estudo que o originou, todo tipo de orla fluvial inserida em espaço urbano, não sendo ocupada por edificações, faz parte do sistema de espaços livres urbanos, independentemente de suas condições de conservação, uso e apropriação pública.

O conceito de espaço livre urbano é definido por Magnoli (2006), sendo esse "todo espaço nas áreas urbanas e em seu entorno, não coberto por edificações" (MAGNOLI, 2006, p. 202), o qual inclui espaços para circulação, praças, parques, cursos d'água, espaços vegetados, áreas de preservação, quintais e os demais espaços não ocupados situados em território urbanizado.

Entretanto, esses espaços não se inserem de maneira isolada na cidade; pelo contrário, são articulados (Figura 4). Um exemplo disso é que, para se chegar a uma praça, é preciso, primeiramente, percorrer uma via. A união ou o agrupamento desses espaços permite compreender que eles funcionam de maneira sistêmica, conformando um Sistema de Espaços Livres Urbanos, ou SEL urbano, no qual também se sobrepõem diversas funções 


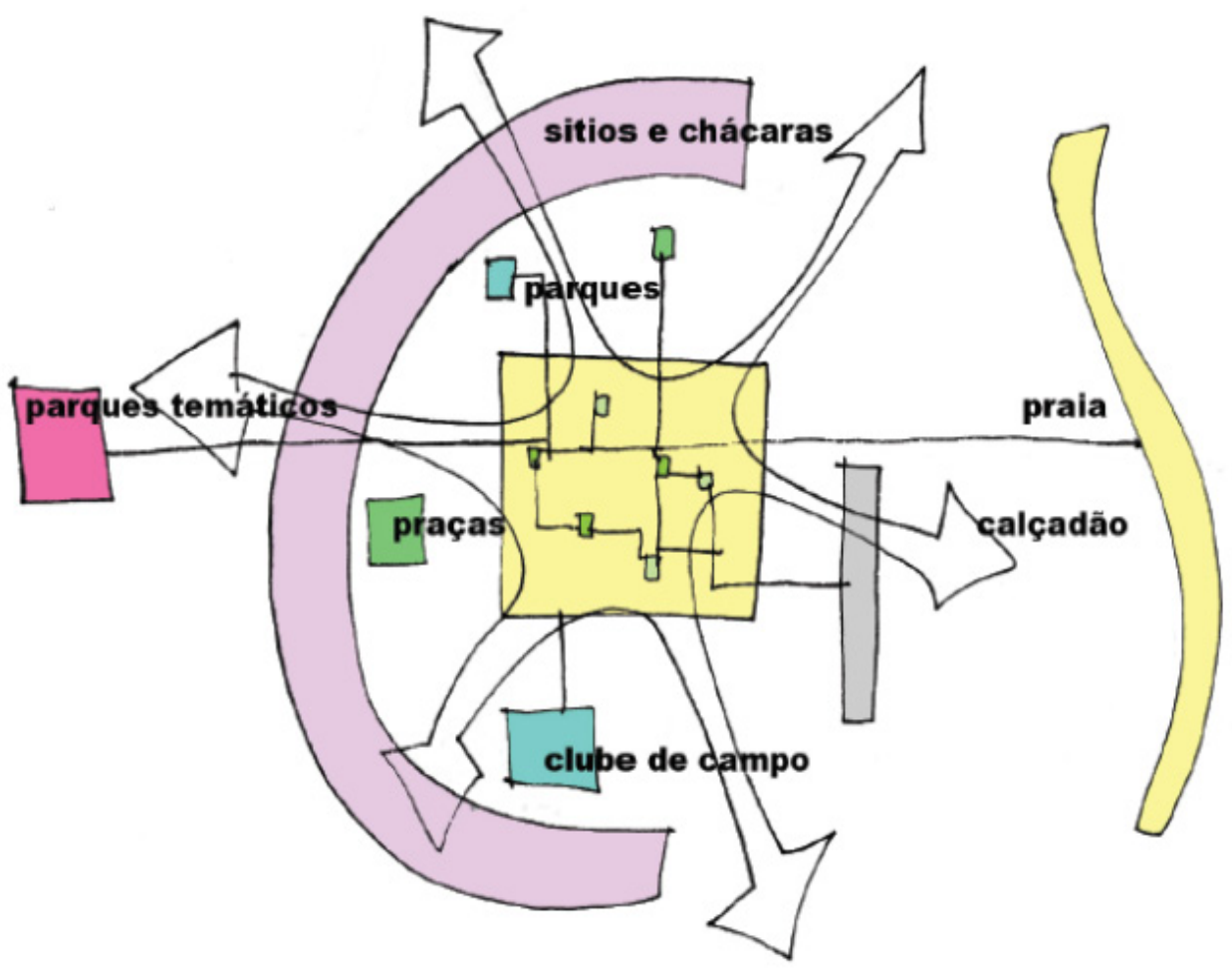

Figura 4 - As diferentes escalas de espaços livres urbanos.

Fonte: Esquema de Sílvio Macedo,

presente em Souza, 2015.

inerentes ao espaço urbano, como a própria circulação, o lazer, a drenagem etc. Apesar de sua complexidade, esses são espaços fundamentais para o cotidiano urbano e para a manutenção do equilíbrio social e ambiental e devem comportar atributos qualitativos essenciais para a manutenção dessas práticas (SOUZA, 2015).

Os espaços fluviais urbanos podem ser considerados como elementos estruturantes do SEL urbano, ou seja, sua presença em meio à cidade condiciona, direta ou indiretamente, seus processos de ocupação. Servem também como uma referência paisagística que

nem sempre é apropriada da melhor forma, de modo a estimular um maior convívio social em seu entorno e melhores condições de preservação ambiental.

São inúmeros os exemplos de áreas portuárias de acesso público, mercados populares e outras estruturas construídas para comportar atividades específicas, que congregam pessoas e práticas sociais de grande vitalidade. O banho de rio, a pesca e o futebol no campinho de várzea ocorrem sem que haja uma organização do espaço ou estruturas adequadas ao ideário de equipamento urbano voltado ao lazer e as práticas sociais (SOUZA, 2015, p. 45). 
Em um país marcado por um processo de urbanização que subjugou os recursos ambientais em favor do amplo desenvolvimento urbano, foi comum a implementação de obras de cunho sanitarista visando o controle de enchentes e a prevenção de epidemias (GORSKI, 2010). Porém, ao mesmo tempo em que ocorria a canalização de cursos d'água ou o aterramento de áreas inundáveis, as práticas sociais que eram desenvolvidas junto aos espaços livres fluviais foram, gradativamente, diminuindo.

Não bastassem os impactos ambientais e sociais provenientes desse tipo de intervenção e da consequente ocupação inadequada de margens de rios, Cunha (2012) alega que as obras de cunho sanitarista, tão comuns em décadas passadas, se mostraram ineficazes em seu principal objetivo: a diminuição dos problemas ligados a inundações. Nesse sentido, a ocupação de espaços fluviais por espaços livres "menos construídos e mais adequados à conservação ambiental pode ser vista como uma diretriz adequada num planejamento em larga escala" (SOUZA, 2015, p. 46).

Como importantes elementos mediadores entre espaço urbanizado e águas, os espaços fluviais devem abrigar não apenas suas funções ambientais de modo equilibrado, mas, também, funções sociais que só podem ser realizadas nesses espaços, como o acesso ao rio e a possibilidade de transposição e acesso à outra margem. A respeito disso, Souza (2015) lista algumas funções que os espaços livres fluviais devem, minimamente, atender, sendo elas a de circulação, transposição, conexão física ou visual, permanência, lazer e conservação ambiental (Figura 5).

As funções que devem ser associadas aos espaços fluviais listadas anteriormente tendem a contribuir para um contato mais harmônico entre espaço urbanizado e suas águas, buscando reverter um quadro de degradação na qual se encontram, corroborando com o que afirma Lúcia Costa (2006) a respeito de uma nova visão dos rios em meio urbano, ou seja, uma visão desses como importantes elementos da paisagem. A respeito disso, a autora afirma que existem três premissas básicas para uma melhor inserção paisagística das águas em meio urbano e que, de certo modo, se mesclam com aquelas apresentadas por Souza (2015), sendo elas: visibilidade, acessibilidade e conectividade (COSTA, L., 2006).
Muitos estudos que se referem a cursos d'água no tecido urbano têm apontado para a importância da visibilidade e do acesso público como critérios relevantes de projeto visando a valorização ambiental. Visibilidade e acesso público ampliam o papel social e cultural das águas urbanas, permitindo o acréscimo do valor de uso coletivo como um dos instrumentos de proteção (...). Para manter estes ecossistemas para o futuro, estas estruturas ambientais da paisagem devem estar visíveis no desenho e na nossa experiência cotidiana da cidade. A ideia de conectividade, por sua vez, traz o entendimento de que as águas participam de um movimento contínuo e interligado (COSTA, L., 2006, p. 149-157 apud PENNA, 2017).

Após a apresentação de conceitos relacionados às margens fluviais, com o objetivo entendê-las como parte da paisagem e do SEL urbano e que, por isso, necessitam abrigar funções ambientais e sociais de importância para o processo de reaproximação, busca-se, a seguir, apresentar, brevemente, o método utilizado na pesquisa desenvolvida, para apreensão dos conflitos e interações presentes no espaço fluvial de Ipaba.

\section{Breve Contextualização Metodológica}

A metodologia aqui adotada para análise da relação entre espaço urbano e espaço fluvial consiste em material elaborado por Souza (2015), que apresenta uma abordagem sistêmica e inter-escalar dos cursos d'água em meio urbano, os entendendo como parte singular do SEL. O trabalho de Souza (2015) é fundamentado nos difundidos métodos do Laboratório Quadro do Paisagismo no Brasil - QUAPÁ, para análise do Sistema de Espaços Livres - SEL - urbanos em cidades brasileiras. O autor propõe estudo de Padrões Morfológicos de orlas fluviais mediante três categorias de análise: Padrões de Configuração Espacial; Padrões de Inserção Urbana; e Padrões de Contato entre as cidades e os corpos d'água. Sua abordagem é realizada em duas escalas: intraurbana, que investiga a relação sistêmica entre cidade e água na escala da cidade; e a escala local, que trata da relação entre orlas fluviais e seu entorno imediato (SOUZA, 2015). 
1

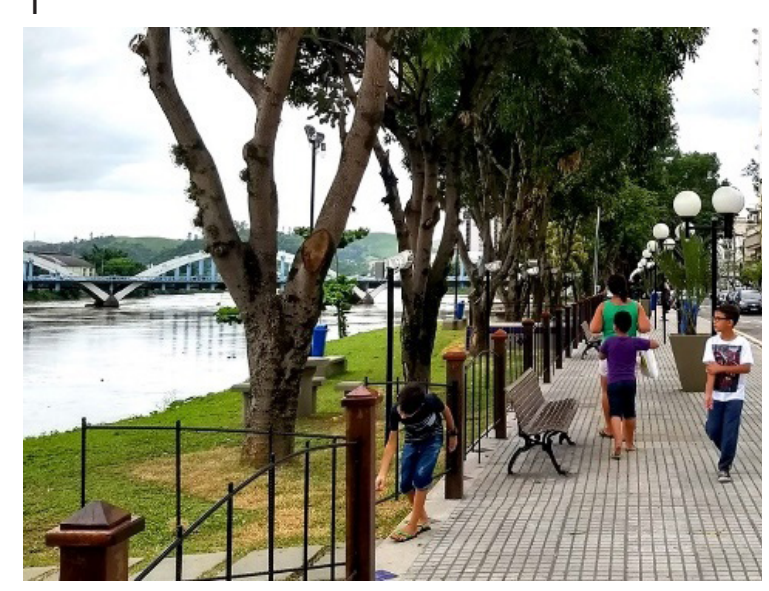

4

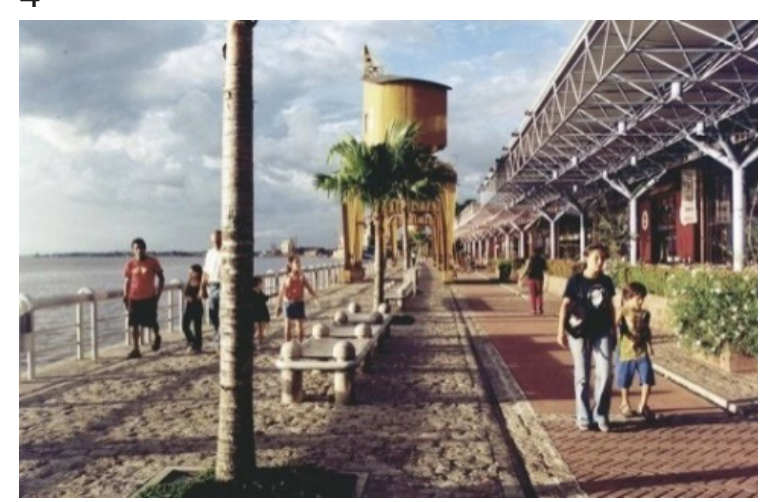

2

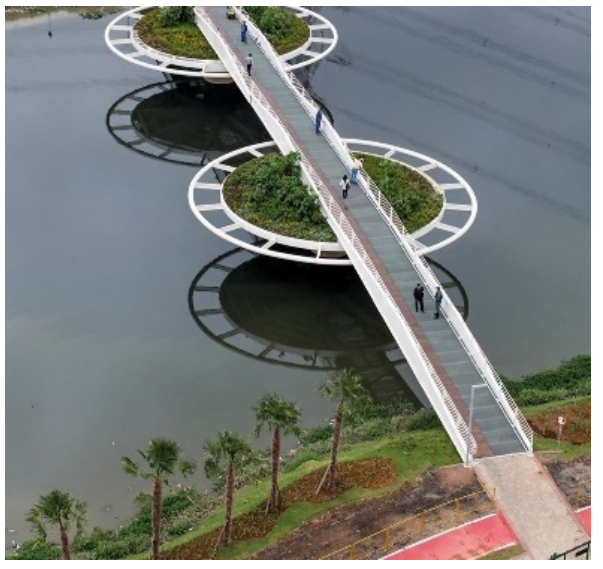

5

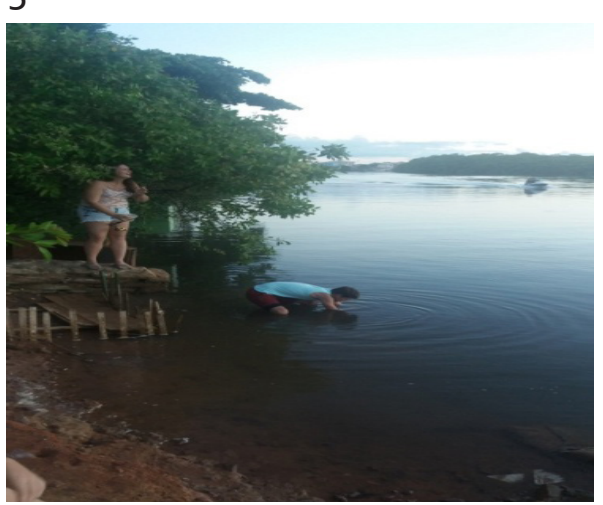

3

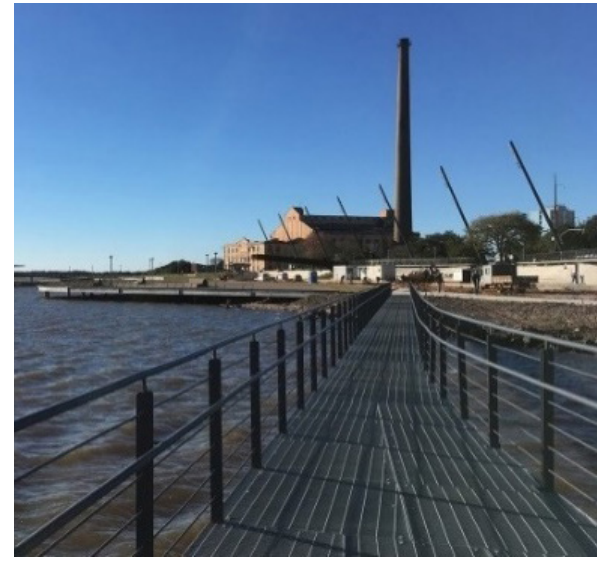

6

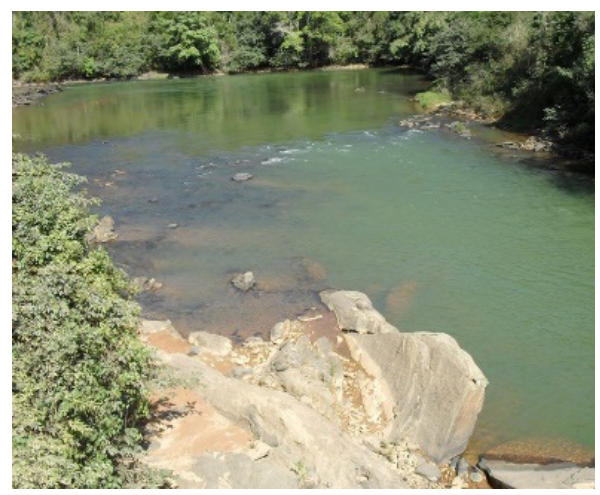

Figura 5 - Mosaico de imagens representando as funções essenciais aos espaços livres fluviais. 1 circulação: Calçadão Dama do Samba, às margens do rio Paraíba do Sul, em Barra Mansa (RJ). 2 transposição: Ponte Friedrich Bayer, sobre o rio Pinheiros, em São Paulo (SP). 3 conexão física ou visual: Orla fluvial do rio Guaíba, em Porto Alegre (RS). 4 permanência: Estação das docas, às margens da Baía de Marajó, em Belém (PA). 5 lazer: Crianças brincando nas margens do rio Fundão (ES). 6 conservação ambiental: Rio Manhuaçu, no município de Caratinga (MG).

Fonte: 1: Disponível em <http://www.cdlbm.com.br/revista-o-lojista/informacoes-gerais/beira-rio:-um-novo-espaco-para-eventos-gastronomicos-em-bm/4871>. 2: Disponível em https://images.adsttc.com/media/images/5746/fbe2/e58e/ce86/5200/025f/large_jpg/46113PR140414-028D - Finotti.jpg?1464269773>. 3: Disponível em <https://www.vitruvius.com.br/revistas/read/arquiteturismo/12.132/6901>. 4: Disponível em <https://www.vitruvius.com.br/revistas/read/resenhasonline/14.164/5638>. 5: Acervo do autor. 6: Disponível em <https://www.flickr.com/photos/quinzequilos/4776787265/in/photostream/>.

Sites acessados em 22 Dez. 2019. 
a) Padrões de configuração espacial: considera-se os diferentes tipos de orlas fluviais em relação a aspectos como conectividade de fragmentação das áreas de interesse ambiental, porte e sua distribuição sobre os trechos que compõem uma bacia hidrográfica, apontando aspectos do desempenho urbano e ambiental.

b) Padrões de inserção urbana: abordam-se as formas como as orlas fluviais estão inseridas na cidade e como se relacionam com o seu entorno, relacionando-as com tipos de tecidos e apontando suas relações com diferentes setores urbanos, considerando a influência que essas condicionantes exercem sobre o desempenho ambiental e urbano.

c) Padrões de contato entre a cidade e os corpos d'água: são discutidos os tipos de interferência que as APPs sofrem no espaço urbano em função dos tipos de canais e de sua relação com a mancha urbana, considerando-se esses aspectos como condicionantes das demandas de uso, acesso e transposição dos corpos d'água (SOUZA, 2015, p. 19-20, grifos do autor).

Neste artigo, são tratados os aspectos referentes aos Padrões de Inserção Urbana, que objetivam analisar, exclusivamente, a articulação entre desenho urbano e margens fluviais. A importância dessa análise se dá, pois "o desempenho urbano e ambiental de um sistema de espaços livres associados às orlas fluviais depende, em grande parte, de sua inserção urbana" (SOUZA, 2015, p. 125). Analisar a inserção urbana de uma orla fluvial não se trata de abordar somente a forma com que essa se insere em meio à cidade, mas, sobretudo, de relacioná-la com seu entorno, compreendendo os tipos de tecidos e os fatores econômicos, sociais e culturais que influenciam em seu processo de produção (SOUZA, 2015).

Outra adaptação da metodologia diz respeito à utilização, somente, da escala de análise local, que trata do estudo do entorno imediato do curso d'água. A escala de análise intraurbana, ou seja, da cidade como um todo (SOUZA, 2015), foi descartada, pois pressupõe investigação da rede hídrica em sua totalidade - canais de menor porte, lagoas etc. -, presente no tecido urbano, diferentemente do objetivo desta pesquisa, que trata de análise exclusiva das margens do rio Doce.

Além disso, depreende-se que o estudo dos Padrões de Inserção Urbana seja suficiente para a compreensão preliminar da relação entre espaço edificado e curso d'água, visto que abrange um leque de aspectos complementares - permeabilidade, usos do solo, atividades produtivas, estrutura viária - e que permite compreender as particularidades de cada tecido urbano a ser estudado. Entretanto, reforça-se que, apesar de não serem abordados os outros Padrões Morfológicos, que tratam de questões hídricas e ecológicas, reforça-se a importância de seu desenvolvimento em estudos futuros, para que os resultados aqui apresentados possam ser complementados.

Nesse sentido, o autor (SOUZA, 2015) sugere que o estudo de inserção de orlas fluviais seja desenvolvido segundo três subcritérios, a saber:

a) Tipos de tecidos: permeabilidade do solo: Avalia-se a forma como os diferentes tipos de tecidos se distribuem ao longo da rede hídrica urbana, considerando-se as influências que exercem sobre sua dinâmica hidrológica, através da incidência de espaços livres e áreas permeáveis.

a) Tipos de tecidos: padrões de urbanização e setores urbanos: Avalia-se a distribuição das orlas fluviais pelos diferentes setores da cidade - centralidades, bairros residenciais, vetores de expansão urbana, entre outros -, considerando-se como se espacializam as diferentes demandas de uso e as pressões socioeconômicas incidentes sobre tais áreas.

a) Tipo de assentamento: estruturação viária: Avalia-se a forma como o sistema viário se estrutura sobre a bacia e no entorno da orla fluvial, tal como a dis- 


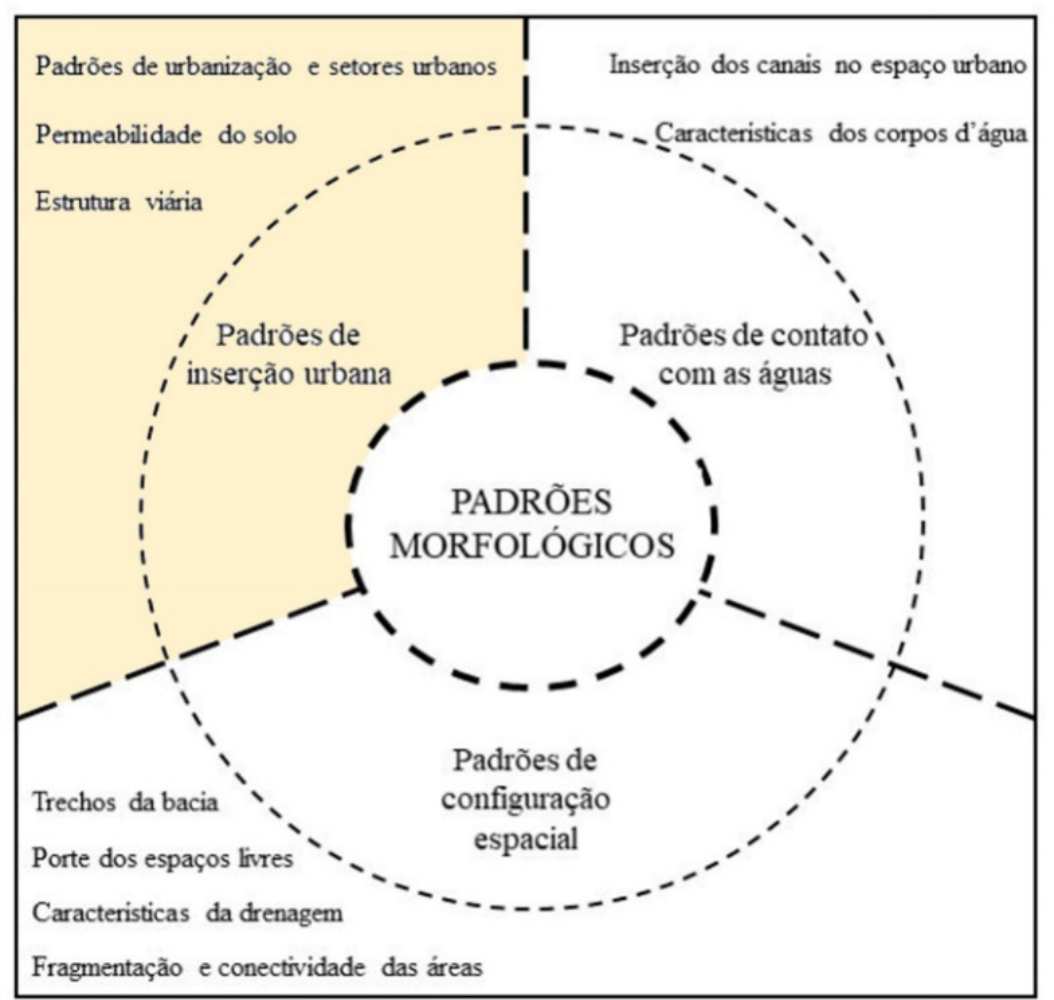

Figura 6 - Diagrama da metodologia de Souza (2015) para análise das margens dos cursos d'água, com destaque para o padrão utilizado neste artigo. Fonte: Adaptado de Silva, 2019.

posição dos lotes e das edificações, considerando-se a acessibilidade dessas áreas, os conflitos e as possibilidades de sua incorporação no espaço urbano (SOUZA, 2015, p. 126, grifos do autor).

A seguir, apresenta-se, por meio da Figura 6, um diagrama da metodologia de Souza (2015), elaborado por Silva (2019) com destaque para os Padrões de Inserção Urbana tratados neste artigo, a partir de três abordagens complementares, sendo elas: Permeabilidade do solo, Padrões de urbanização e setores urbanos e estrutura viária.

\section{Conflitos e Interações Presentes no Espaço Fluvial de IPABA, MG}

A análise das margens do rio Doce inseridas no município de Ipaba teve como trecho analisado a região do Distrito Sede, onde se insere o principal núcleo urbano do município e onde estão presentes suas principais dinâmicas socioeconômicas. A fotografia aérea a seguir (Figura 7) ilustra o trecho de análise.

\section{TIPOS DE TECIDOS: PERMEABILIDADE DO SOLO}

Como já mencionado, a região Sede de Ipaba está localizada em região periférica à RMVA, com características predominantemente rurais. A área urbana pode ser acessada pela rodovia Gessi de Assis Pena e Avenida José Rodrigues de Almeida, ramais da rodovia federal BR-258. Os trilhos da EFVM, diferentemente de muitos municípios do Vale do Rio Doce, não atravessam o núcleo urbano, estando localizados na porção oposta das margens do rio Doce, junto ao distrito de Ipaba do Paraíso (Ipabinha).

A área de ocupação urbana se insere no entroncamento dos ramais rodoviários e tem por característica a compactação e elevada densidade construtiva. A despeito da área urbana compacta e altamente impermeável, que está inserida nas proximidades do rio Doce, pode ser observada, no trecho de análise, quantidade significativa de áreas livres permeáveis, que ocupam a maior parte das margens do curso d'água (Figura 8).

Para análise da permeabilidade do solo, adotou-se como referência a legislação municipal que trata do controle do uso e ocupação do solo em área urbana. Importante destacar que, por ser um município incipiente em termos econômicos e populacionais, foi somente em 2019 que o município passou a contar com esse tipo de regulamentação, por meio da aprovação e sancionamento da Lei no 814/2019, que institui e aprova o plano de expansão do perímetro urbano. 0 fato de não contar com políticas próprias de planejamento do espaço urbano favoreceu o processo de desordenamento paisagístico e ocupacional no qual Ipaba se encontra atualmente. A paisagem urbana local, que ora se mescla com áreas rurais, possui predomínio 


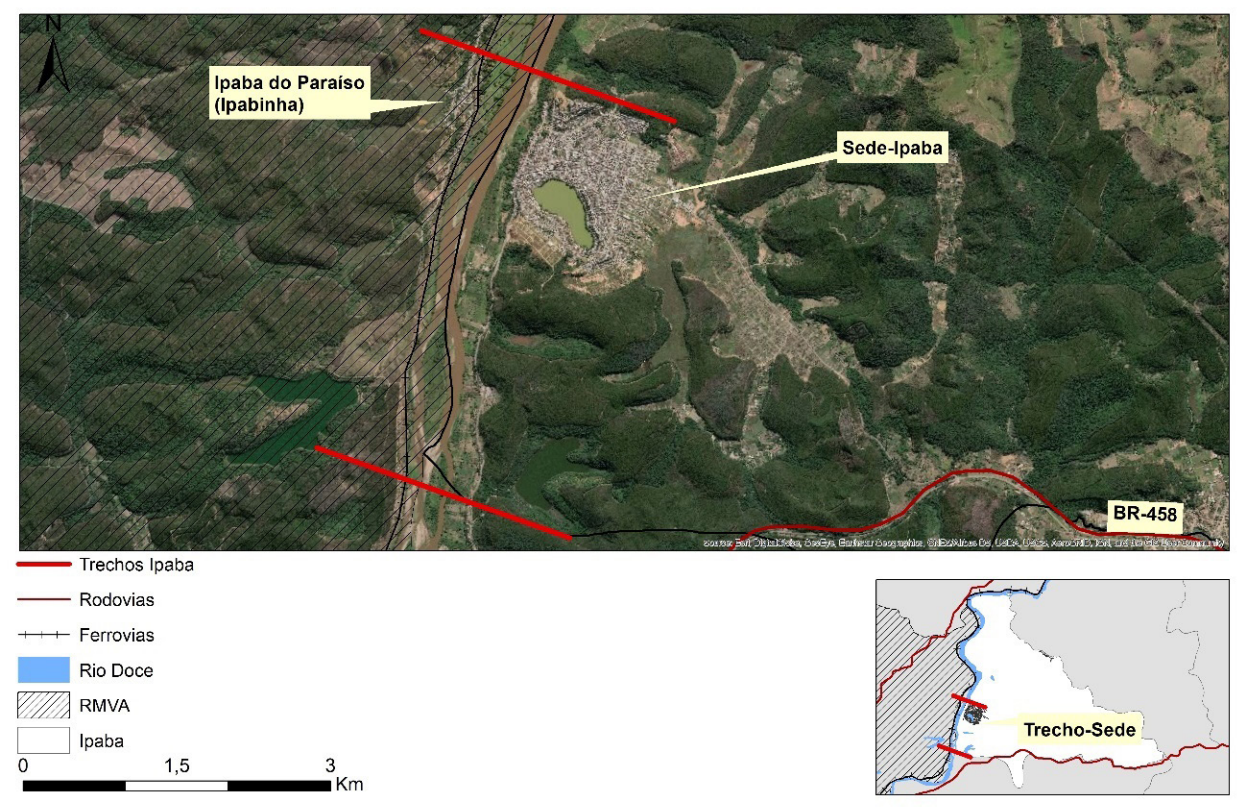

Figura 7 - Imagem aérea do trecho analisado junto ao município de Ipaba.

Fonte: Elaborado pelos autores, 2020

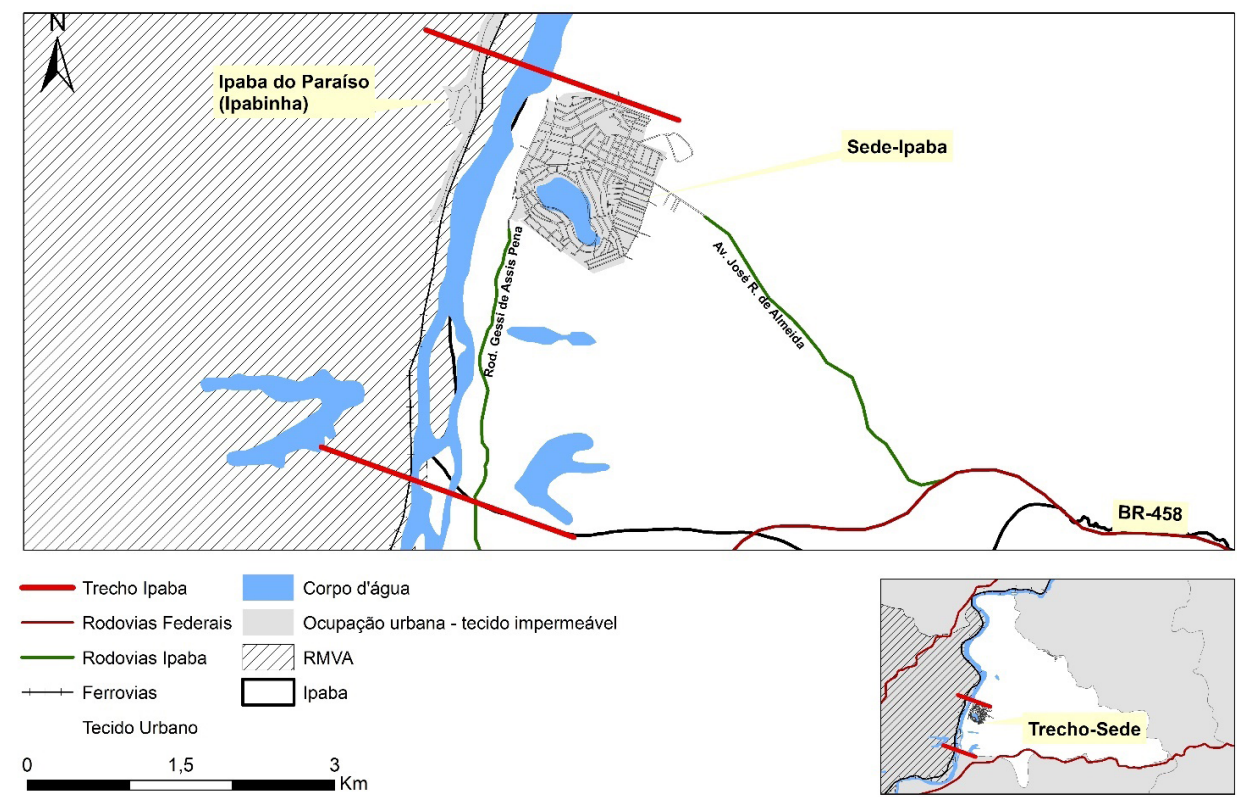

Figura 8 - Permeabilidade do solo do Trecho 1, em Ipaba. Fonte: Elaborado pelos autores, 2020 
de características de zonas periféricas. Desse modo, o resultado do adensamento das construções, juntamente com a escassez, tanto de espaços livres de uso público quanto de espaços livres intra-lote, foi de elevado índice de impermeabilidade na área urbana consolidada.

De acordo com o plano de expansão do perímetro urbano de Ipaba (IPABA, 2019), inserem-se, no trecho de análise, três zonas urbanas, sendo elas: Área sem restrição à ocupação, denominada neste trabalho de ASO, Área com restrição à ocupação (ACO), e Área com controle especial de ocupação, denominada ACEO.

A região inserida na ASO corresponde à área urbana consolidada, e para ela não são definidas diretrizes de ocupação, como área mínima de lotes, taxa de ocupação máxima e taxa de permeabilidade mínima. Segundo a lei (IPABA, 2019), nessas áreas, o parcelamento do solo deve seguir os parâmetros dispostos da Lei Federal $n^{\circ}$ 6.766/1979 (BRASIL, 1979) e das legislações estaduais e municipais pertinentes. Do ponto de vista da permeabilidade, a lei municipal somente afirma que nas ASO, o parcelamento do solo não poderá ocorrer em terrenos alagadiços e sujeitos a inundações, sem que sejam tomadas medidas de escoamento das águas.

Com relação às $A C O$, a lei informa que essas dizem respeito às áreas da Cenibra e áreas para plantio de eucalipto, considerando-as não parceláveis. Desse modo, não são enumerados índices de ocupação para essas áreas. Além disso, a lei não informa o motivo pelo qual a área não pode ser alvo de parcelamentos. No entanto, diante de sua potencialidade em se tornar parcelável no futuro, entende-se que se trata de fato de previsão de áreas de expansão, onde atualmente se insere eucalipto, como uma reserva para garantir valor à terra. Nesse contexto, nota-se que a maior parte do trecho analisado é composto por áreas privadas e teoricamente permeáveis, destinadas à monocultura do eucalipto, tendo, portanto, pouco ou nenhum proveito, atualmente, para a esfera pública urbana.

Já as ACEO são consideradas pela lei como aquelas inseridas em parcelamentos do solo urbano onde incida qualquer proporção de trechos sujeitos a controle especial em função de ameaças de desastres naturais (IPABA, 2019). Estão situadas entre a faixa de APP do rio Doce, definida pelo município em 100 metros lineares a partir do rio, e a Rodovia Gessi de Assis Pena. Trata-se também do único tipo de zona, definido pela lei municipal, que possui algum índice de ocupação, visto que é determinado para lotes inseridos em ACEO, área de 30\% de terreno permeável. Para essas áreas, também devem ser definidos locais para instalação de equipamentos específicos de drenagem e infiltração das águas pluviais. A Tabela 1 e a Figura 9 indicam, respectivamente, as taxas definidas para as áreas inseridas no trecho analisado e as áreas correspondentes ao zoneamento.

Tabela 1 - Índices de ocupação do solo definidos para Ipaba. Observa-se que a lei municipal é pouco específica ao, praticamente, não definir critérios de ocupação.

\begin{tabular}{l|c|c|c}
\hline \multicolumn{1}{c|}{ Zonas } & $\begin{array}{c}\text { Área } \\
\text { mínima } \\
\text { dos } \\
\text { lotes } \\
\left(\mathrm{m}^{2}\right)\end{array}$ & $\begin{array}{c}\text { Taxa } \\
\text { de ocupação } \\
\text { máxima } \\
(\%)\end{array}$ & $\begin{array}{c}\text { Taxa } \\
\text { de } \\
\text { permeabili- } \\
\text { dade } \\
\text { mínima }\end{array}$ \\
\hline $\begin{array}{l}\text { Área sem } \\
\text { restrição à } \\
\text { ocupação } \\
\text { (ASO) }\end{array}$ & - & - & - \\
\hline $\begin{array}{l}\text { Área com } \\
\text { restrição à } \\
\text { ocupação } \\
\text { (ACO) }\end{array}$ & - & - & \\
\hline $\begin{array}{l}\text { Área com } \\
\text { controle } \\
\text { especial de } \\
\text { ocupação } \\
\text { (ACEO) }\end{array}$ & & & \\
\hline
\end{tabular}



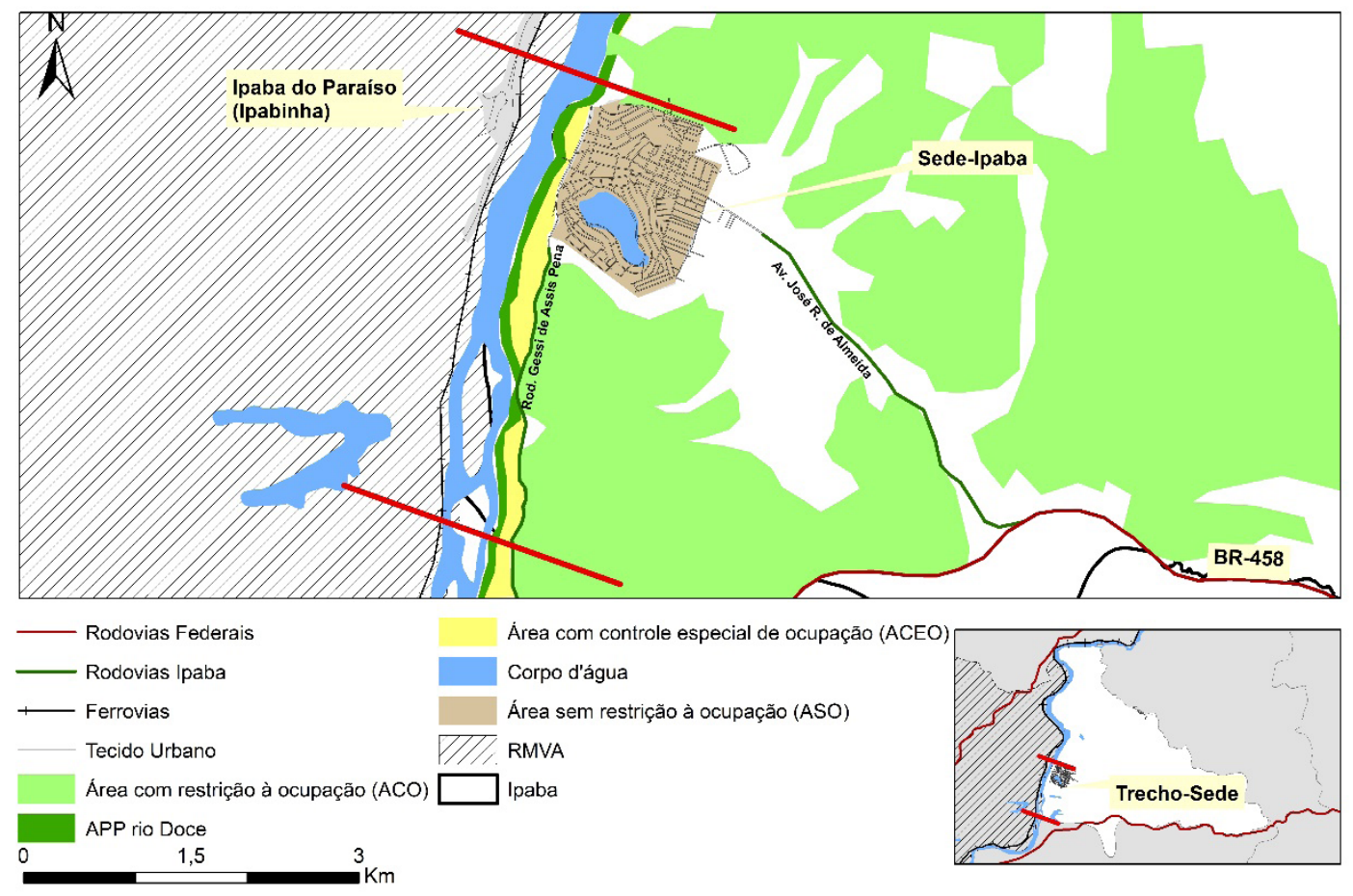

14

Apesar de a lei municipal mostrar relativa preocupação com disponibilidade de área permeável às margens do rio Doce, sobre a qual se insere a ACEO, estabelecendo área de permeabilidade superior ao que é visto em grande parte das legislações municipais da região, é preocupante o fato de a lei legitimar a urbanização da faixa de APP do curso d'água, sem estabelecer critérios específicos de urbanização. Esse fato pode acarretar aumento da área impermeável, sem o necessário controle, sobre uma região que ainda possui significativo estoque de áreas livres.

Quanto à lei, merece também destaque, além da ausência de índices urbanísticos que orientem a construção, o fato de não apresentar um zoneamento mais detalhado, diferenciando como as partes da área urbana devem ser tratadas. A existência de um zoneamento genérico e abrangente pode dar margem à aprovação de projetos urbanos discrepantes do ponto de vista paisagístico e, também, quanto à disponibilidade de área permeável no terreno, poden- do agravar os impactos provenientes da redução da infiltração da água no solo.

\section{Padrótes de uRbanização e setores uRbanos}

As margens do rio Doce, no trecho analisado de Ipaba, estão totalmente inseridas em setor destinado à produção agrícola. Nessas áreas estão presentes sítios, chácaras, áreas vegetadas, pastagens e demais ocupações ligadas a esse setor produtivo (Figuras 10 e 11). A inserção da Rodovia Gessi de Assis Pena, de modo paralelo ao rio e a esse setor, proporciona, em determinados pontos, a visualização do curso d'água e das áreas agricultáveis. A existência de considerável desnível na região das margens do rio Doce pode ter sido determinante para sua ocupação por áreas agricultáveis e não pelo tecido urbano. 

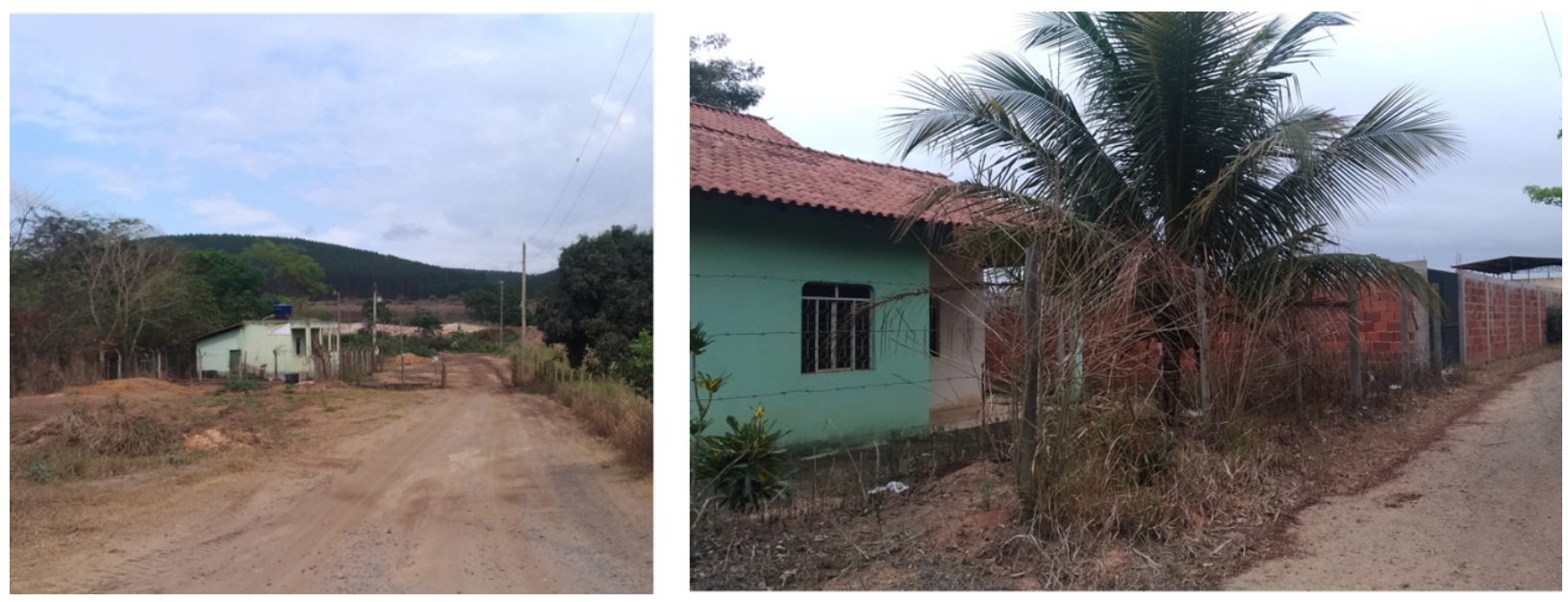

Figura 10 - Ocupações às margens do rio Doce, em Ipaba.

Fonte: Acervo da pesquisa, 2020
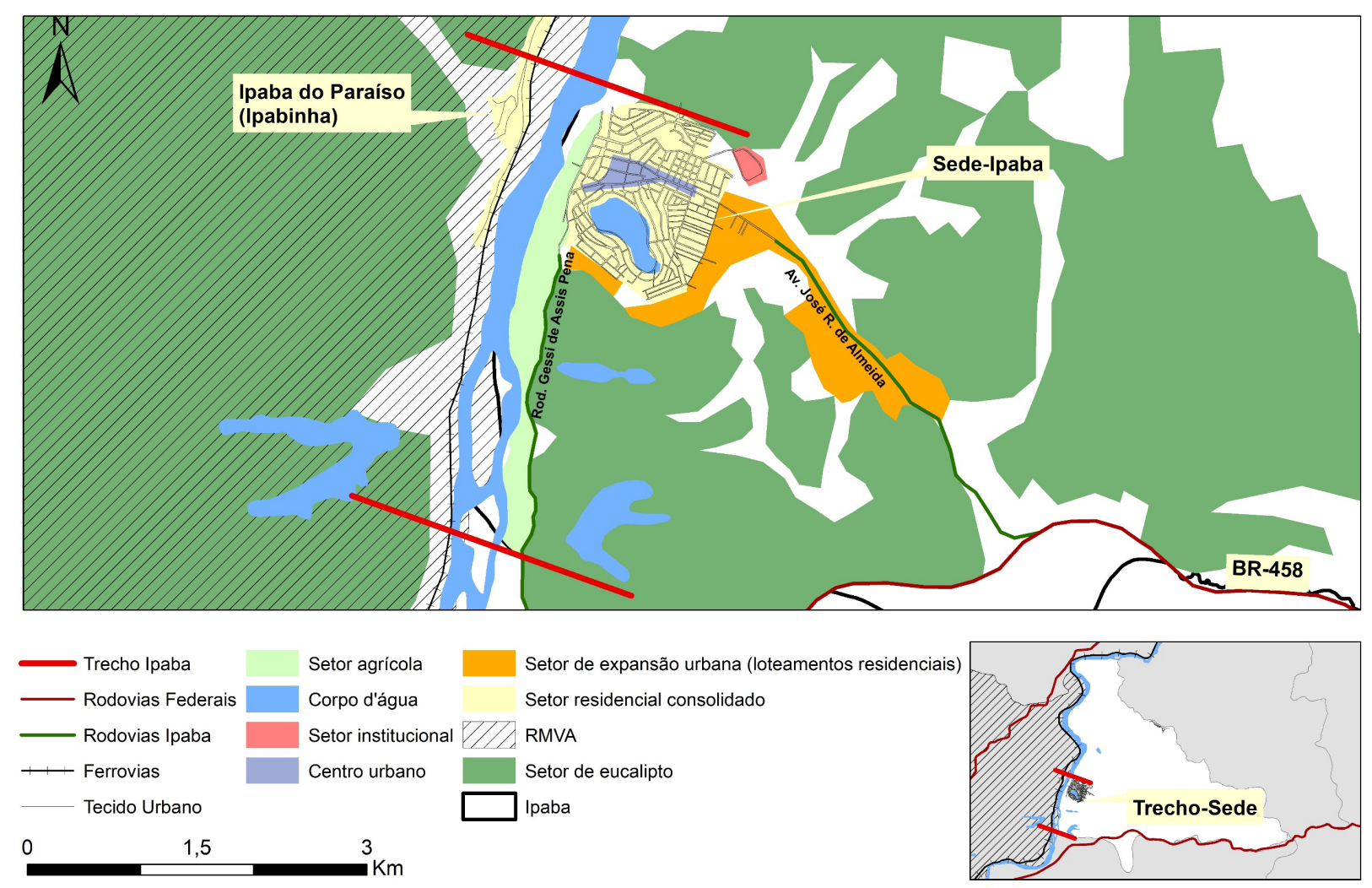

Figura 11 - setores urbanos associados à orla fluvial de Ipaba.

Fonte: Elaborado pelos autores, 2020 
Chama atenção, no local, que parte da vegetação natural foi posta abaixo, dando lugar à ocupação destinada à agricultura. Como se sabe, a conservação da vegetação ciliar é de extrema importância para o equilíbrio ambiental de um rio, mantendo a estabilidade do solo e protegendo as águas de poluentes. Sua retirada e substituição por determinadas atividades de plantio, pode acarretar o carregamento de partículas para o interior do curso d'água, resultando no assoreamento de seu leito.

Já o setor de predominância na região adjacente às margens do rio Doce, corresponde ao setor de plantio de eucalipto, que, por sua vez, passou a ser incorporado à área urbana de Ipaba a partir do plano de expansão do perímetro urbano municipal (IPABA, 2019), sendo incorporado à $\mathrm{ACO}$. Como já abordado nos tópicos anteriores, a paisagem não só de Ipaba, mas de boa parte do Vale do Aço, possui o eucalipto como plano de fundo (Figura 12). Em 2017, sua área de manejo atingiu a marca de, praticamente, 254.000 hectares (CENIBRA, 2018). Os extensos latifúndios da Cenibra conformam e estruturam não só a paisagem, mas a disposição territorial e econômica da região, ditando os vetores de crescimento dos municípios do Vale do Aço. Em Ipaba, a proximidade das reservas de eucalipto com a margem do rio Doce traz consigo os impactos socioambientais inerentes ao seu plantio e que merecem especial atenção no município, sobretudo nas APPs do Doce, dos quais se destacam: a diminuição da disponibilidade de água subterrânea e dos corpos d'água e a perda de produtividade de terras (COSTA, H., 2000).

$\mathrm{O}$ setor residencial consolidado corresponde à maior parte da área urbana de Ipaba. Sua população ocupante é predominantemente de classe média e baixa e não existe padronização em termos de tamanho e disposição de lotes, bem como das edificações, visto que a população foi o principal agente produtor desse espaço (Figura 13). Nessa região também se insere um centro comercial muito característico de cidades de menor porte, onde comércios e serviços estão dispostos ao longo das principais avenidas da cidade. $O$ rio Doce, entretanto, pouco se relaciona com esses setores, apesar de sua relativa proximidade.

$\mathrm{Na}$ adjacência do setor residencial, insere-se a penitenciária de Ipaba. Esse local, e sua inserção em Ipaba, ou seja, distante dos principais centros econômicos do Vale do Aço, é tratado pelo grupo Arte/Cidade (2004) como expressão do contexto de exclusão social e econômica no qual o município se encontra.

Apesar de ser o município do vale do rio Doce com pior índice de qualidade de vida, Ipaba tem apresentado elevado dinamismo populacional nos últimos anos, característica essa, proveniente de sua posição socioeconômica e geográfica em meio ao Colar Metropolitano da RMVA. Em consequência disso, sua mancha urbana tem crescido. Porém, o que chama atenção diz respeito ao seu vetor de crescimento, em sentido oposto ao rio, de forma perpendicular às suas margens ao longo da Avenida José Rodrigues Moreira, em sentido à BR-458.

Nesse contexto, o setor de expansão urbana é marcado por dois cenários distintos. Nas bordas do setor residencial consolidado, caracteriza-se por loteamentos residenciais, relativamente mais padronizados que o restante da cidade, com algumas instalações institucionais e galpões industriais. Conforme se distancia da área urbana consolidada, ao longo da Avenida José Rodrigues Moreira, a expansão urbana se dá por loteamentos abertos, ocupados por chácaras e sítios. A consolidação desses loteamentos e, consequentemente, do vetor de expansão, ocorre em áreas anteriormente destinadas ao plantio de eucalipto.

\section{TIPOS DE ASSENTAMENTO: ESTRUTURAÇÃO VIÁRIA}

As margens do rio Doce, no trecho analisado, estão totalmente inseridas nas tipologias correspondentes à ocupação por setor agrícola (Tipos 3 e $4^{2}$ ) (Figura 14). Na proximidade do Centro, predomina o Tipo 4, em que fundos de lotes estão voltados para a área rural e para o rio. Já o Tipo 3, em que o sistema viário urbano é voltado para a propriedade rural, sem a interferência de lotes urbanos, predomina nas adjacências da área urbana, ao longo da Rodovia Gessi de Assis Pena (Figura 15). Em ambos os casos,

\footnotetext{
$2 \mathrm{Em}$ pesquisa de Croce (2020), foram identificados nove tipos de assentamentos inseridos nos espaços fluviais das cidades do Vale do Rio Doce. Pelo fato de possuir uma área urbana de pequenas dimensões, além de ter características predominantementes rurais, Ipaba apresentou somente dois tipos, 3 e 4, que correspondem a modelos de contato entre cidade e rio por meio de propriedades privadas agrícolas.
} 


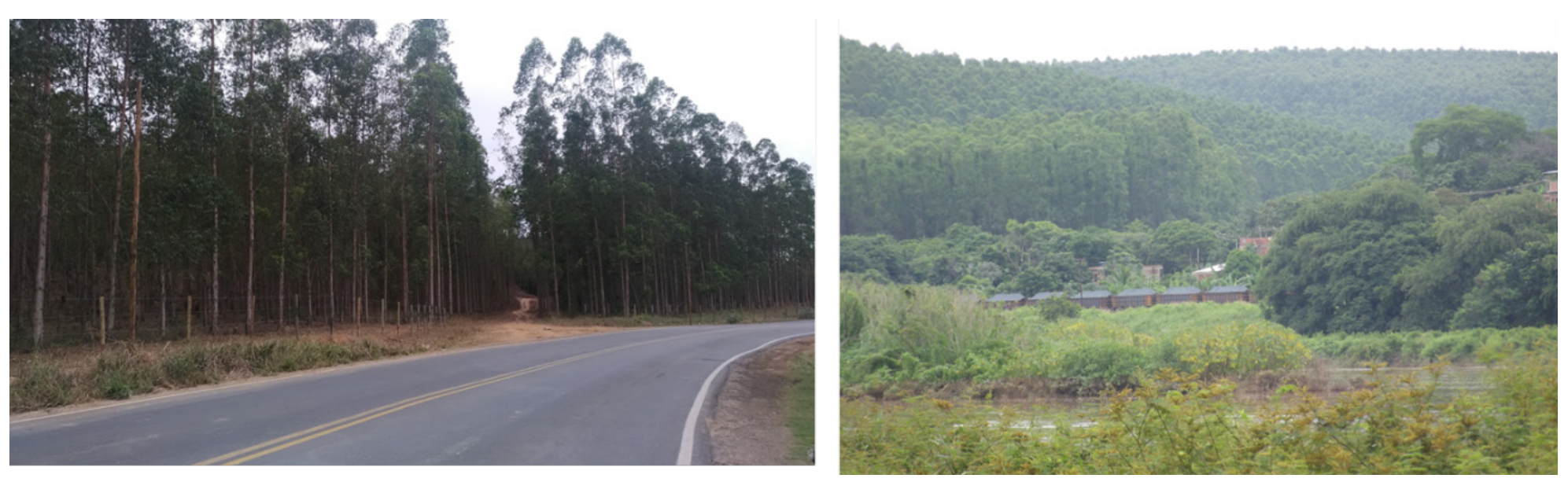

Figura 12 - Monocultura de eucalipto nas proximidades do rio Doce, em Ipaba Fonte: Acervo da pesquisa, 2019.

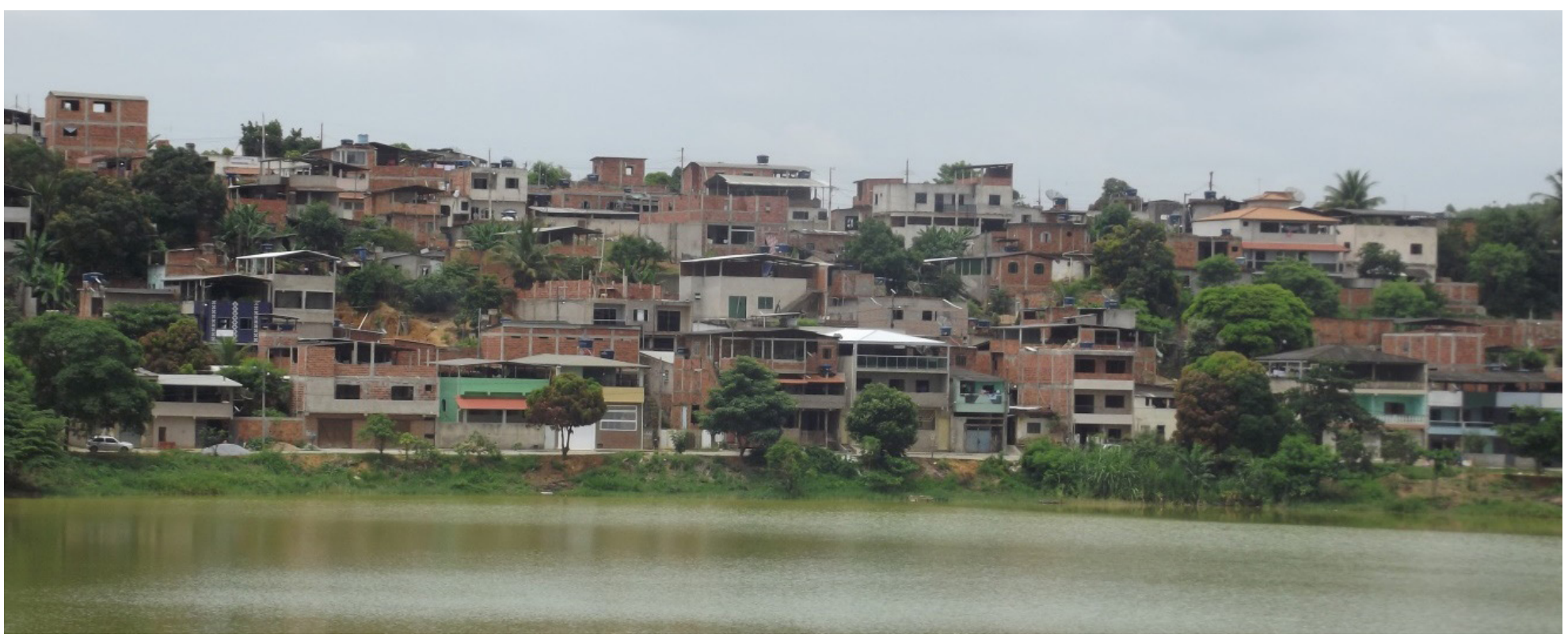

Figura 13 - Vista da área urbana consolidada de Ipaba, às margens da lagoa central. Fonte: Acervo da pesquisa, 2019. 

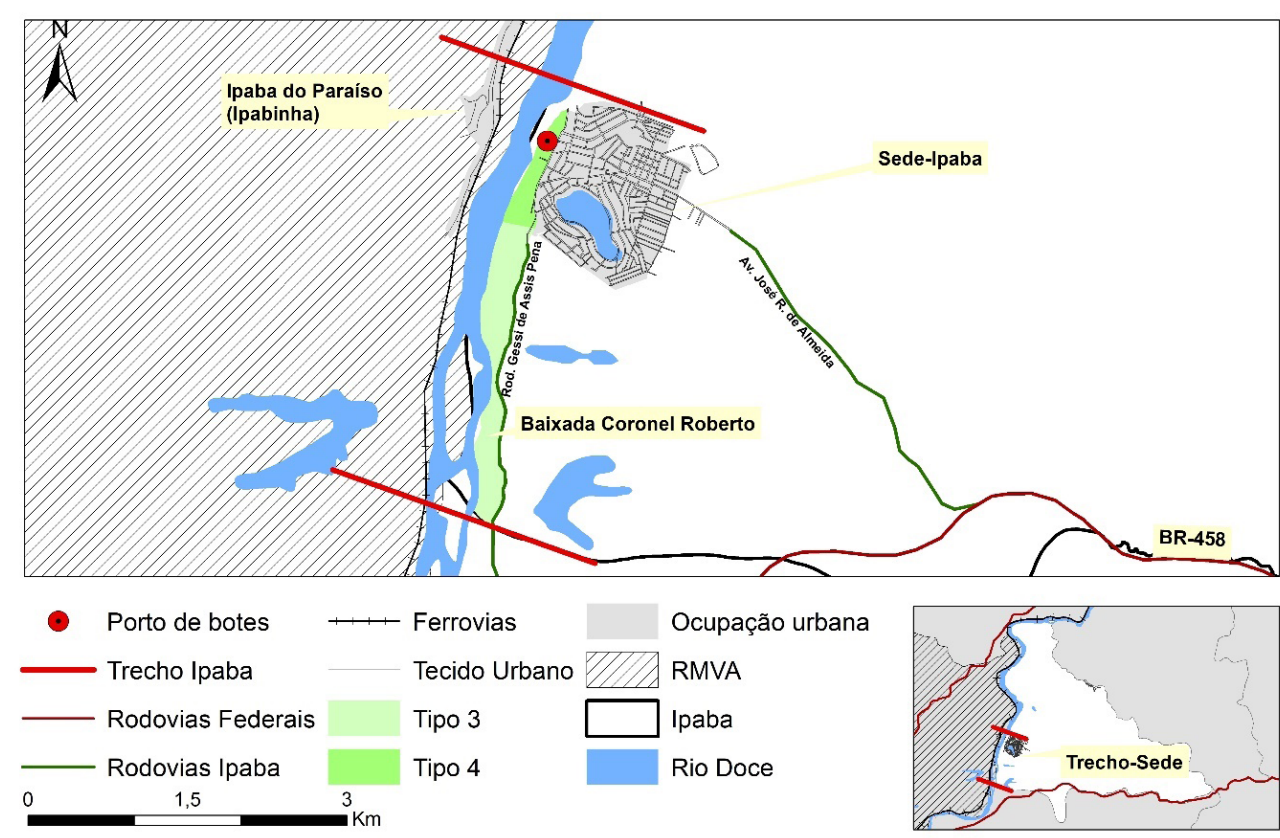

18
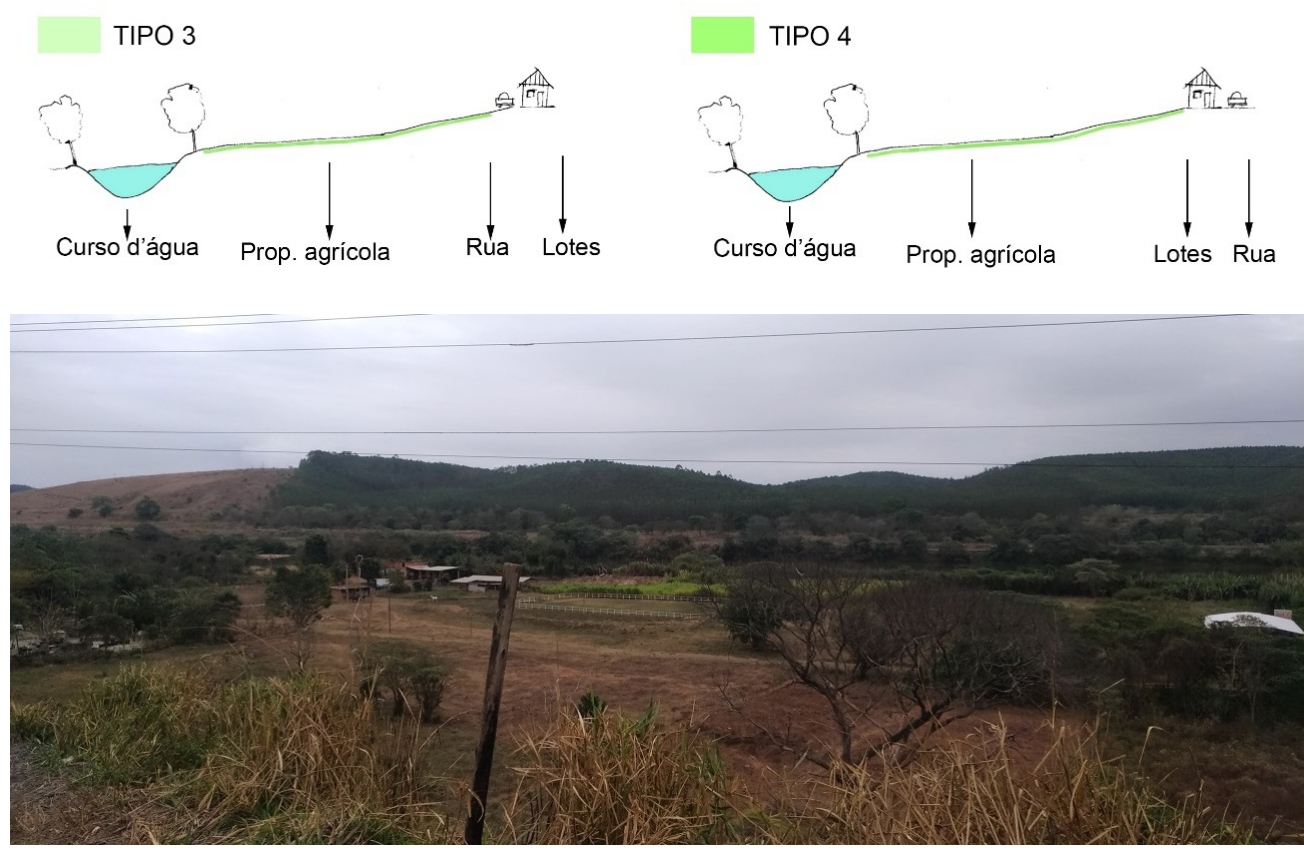

Figura 15 - Propriedade agrícola inserida entre a rodovia Gessi de Assis Pena e o rio Doce.

Fonte: Acervo da pesquisa, 2019
Figura 14 - Padrões de assentamento e estrutura viária no Trecho 1, em Ipaba.

Fonte: Elaborado pelos autores, 2020. 
o acesso físico e visual ao rio é prejudicado. Entretanto, na área urbana, é possível observar um único ponto de acessibilidade física, em rua íngreme e de difícil translado, que dá acesso ao porto de botes. A predominância dessas tipologias de assentamento, juntamente com a ausência de tratamento adequado das margens fluviais, faz com que o rio sequer possa ser notado na área urbana consolidada. Somente alguns pontos situados em áreas de maior elevação permitem sua visualização (Figura 16). Segundo Lucia Costa (2006) e Mello (2008), a visualização de um curso d'água é fundamental para que exista apropriação social de suas margens e, consequentemente, sejam criadas medidas para sua proteção ambiental.

A área do porto, apesar de possuir enorme potencialidade para promover aproximação entre a cidade e o rio, não tem o mínimo tratamento urbanístico e paisagístico, conforme mostra a Figura 17. A realidade presenciada evidencia vegetação degradada, insegurança e ausência de urbanidade. Sua utilização atual se dá tanto como área de embarque quanto como pasto para gados. A inserção urbana da via que dá acesso ao local também prejudica sua apropriação, visto que a presença dos lotes a torna praticamente invisível.

A região em que predomina o Tipo 3 corresponde à localidade da Baixada Coronel Roberto, local ocupado por pequenos agricultores, situado entre a rodovia que dá acesso à Ipaba e o rio Doce, situando-se em sua APP fluvial. O local é ocupado por chácaras e pequenas propriedades rurais, em que os proprietários cultivavam animais e hortaliças, abastecendo o mercado agrícola regional e gerando renda para algumas famílias.

Apesar da ser uma conexão de aspecto privado, que produz pouco ou nenhum proveito para a apropriação social das margens do rio Doce, entende-se que a relação da comunidade com o curso d'água tem grau de importância, considerando que o mesmo representa fonte de subsistência para algumas famílias, que o utilizam para dessedentação de animais e irrigação de suas lavouras. Entretanto, com a chegada, em Ipaba, da lama de rejeitos proveniente da barragem da Samarco, tanto a conexão física quanto a conexão social dos moradores com o rio foram perdidas.
No aspecto social, a contaminação do rio Doce, além de gerar a morte de animais e a destruição de plantações, tornou o local improdutivo. Muitas famílias tiveram forte prejuízo econômico. No aspecto físico, a chegada da lama, as incertezas por detrás do ocorrido e a improdutividade do solo, inviabilizaram a manutenção das propriedades locais gerando, consequentemente, processo de expropriação da população (Figura 18). A proibição da pesca no rio logo após o desastre-crime também prejudicou economicamente os pequenos agricultores. Diversas propriedades foram postas à venda. A região se encontra em estado precário, de descuido. Foram notados inúmeros focos de lixo, propriedades abandonadas e solos em mau estado de conservação. Chamou atenção a quantidade de placas de vendas voltadas para rodovia. Com a queda de produtividade, os preços das chácaras despencaram e, mesmo assim, constata-se reduzida procura pelas terras.

Além disso, também não podem ser perdidos de vista os impactos ocasionados pela lama de rejeitos no deslocamento da população de Ipaba do Paraíso (Ipabinha) e de Ipaba que, como já mencionado, foi inviabilizada devido aos constantes episódios de danificação dos botes que realizam a travessia. Situação essa que dirimiu a conexão física entre os dois locais e, consequentemente, a apropriação que se tinha das margens do rio por meio dessa atividade.

Essa situação reforça o contexto de ausência de articulação entre o tecido urbano das duas margens do rio Doce, ou seja, entre o Distrito Sede de Ipaba e Ipabinha. Em situações de conexão, por meio da construção de pontes ou passarelas, essa relação histórica de precariedade na transposição do rio poderia ser amenizada (Figura 19). É importante considerar, também, conforme estudo socioeconômico do vale do rio Doce, que Ipaba se insere em região de periferia metropolitana, onde, atualmente, o valor do solo não é elevado, e não existe maior interesse, por parte dos agentes produtores do espaço urbano, no investimento em melhorias estruturais para o local (CROCE, 2020).

Ao contrário de municípios de maior porte, como Colatina e Governador Valadares, observa-se que em Ipaba as margens do rio Doce não são tão valorizadas pelo mercado imobiliário e, por isso, não existe pressão por sua ocupação. A ausência de espaços destinados 


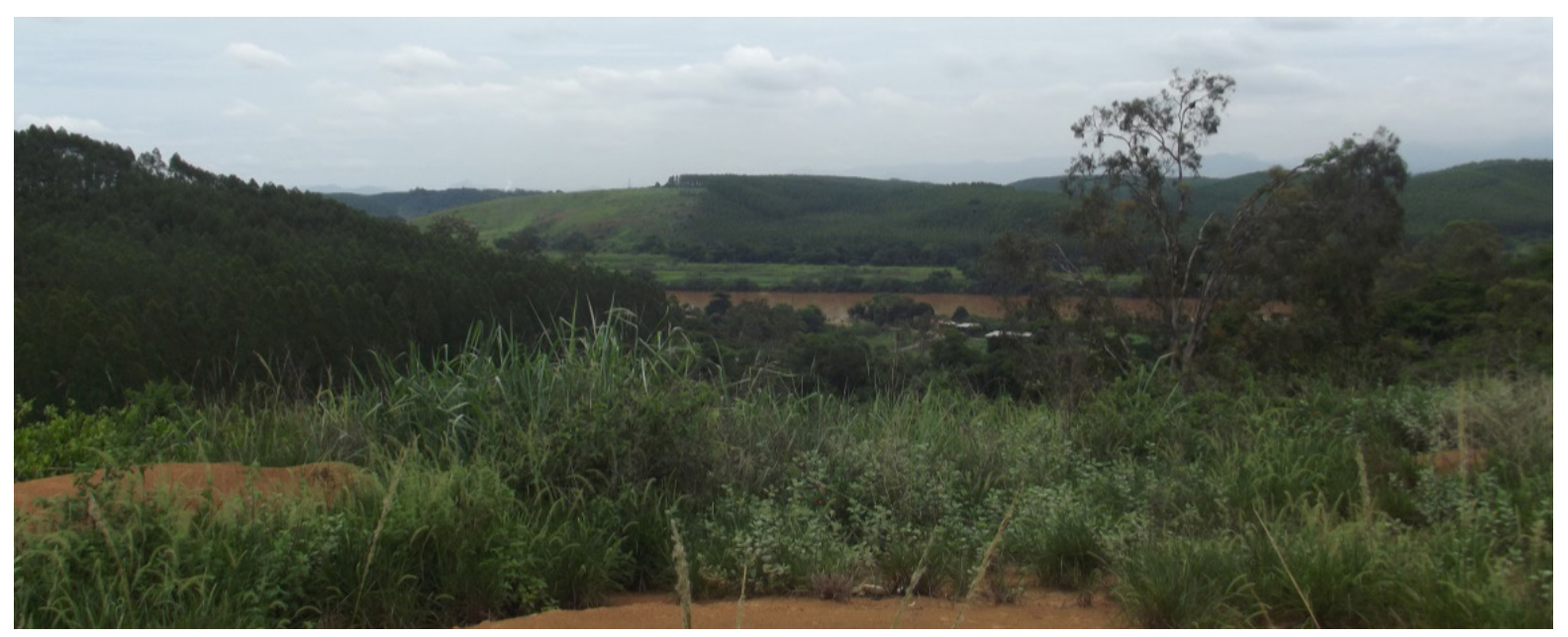

20

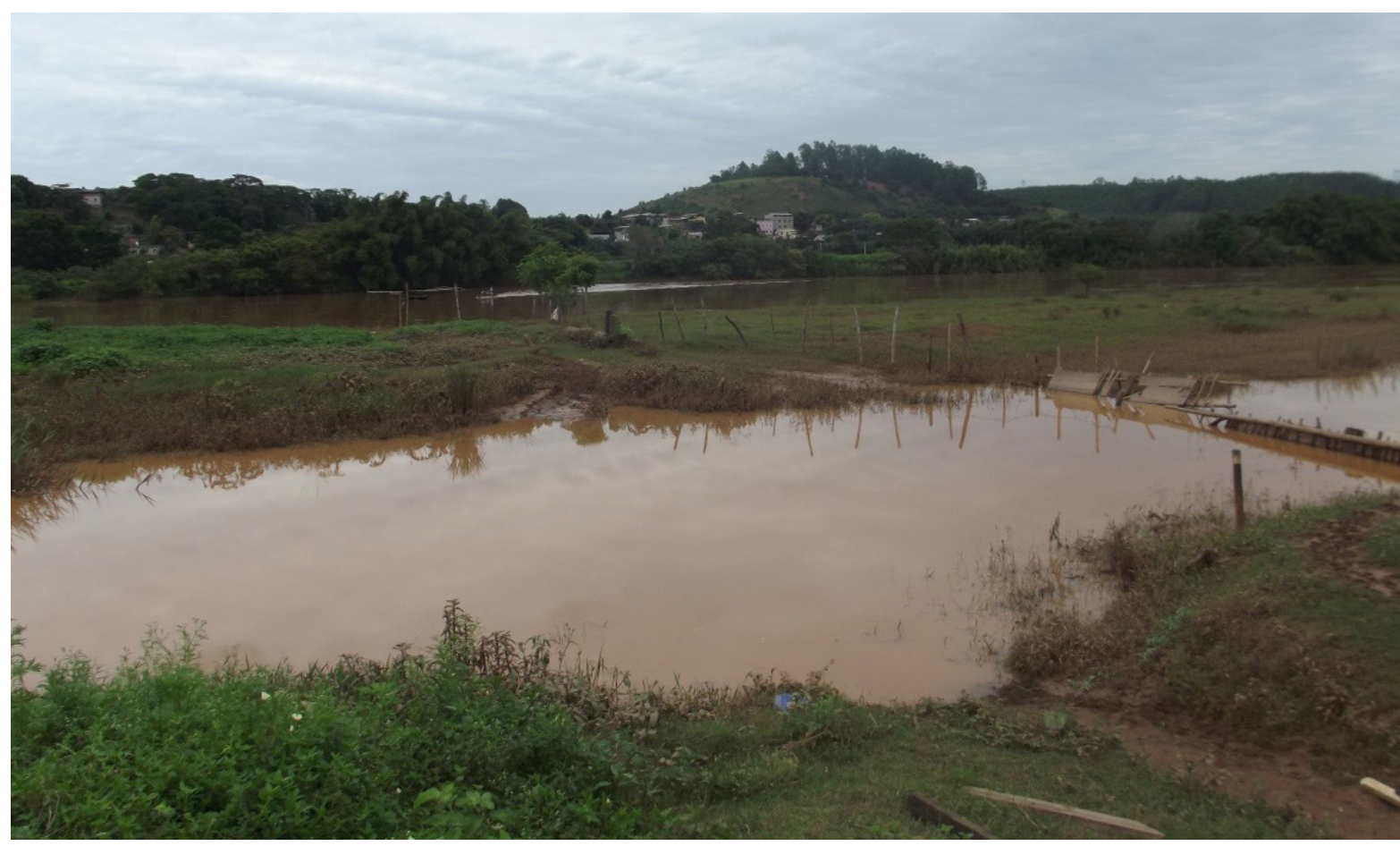

Figura 16 - Ao fundo, vista do rio Doce em uma colina de Ipaba. Um dos poucos pontos onde se é possível observar o rio. Fonte: Acervo da pesquisa, 2019.

Figura 17 - Margens do rio Doce, na área do porto de botes.

Fonte: Acervo da pesquisa, 2019. 

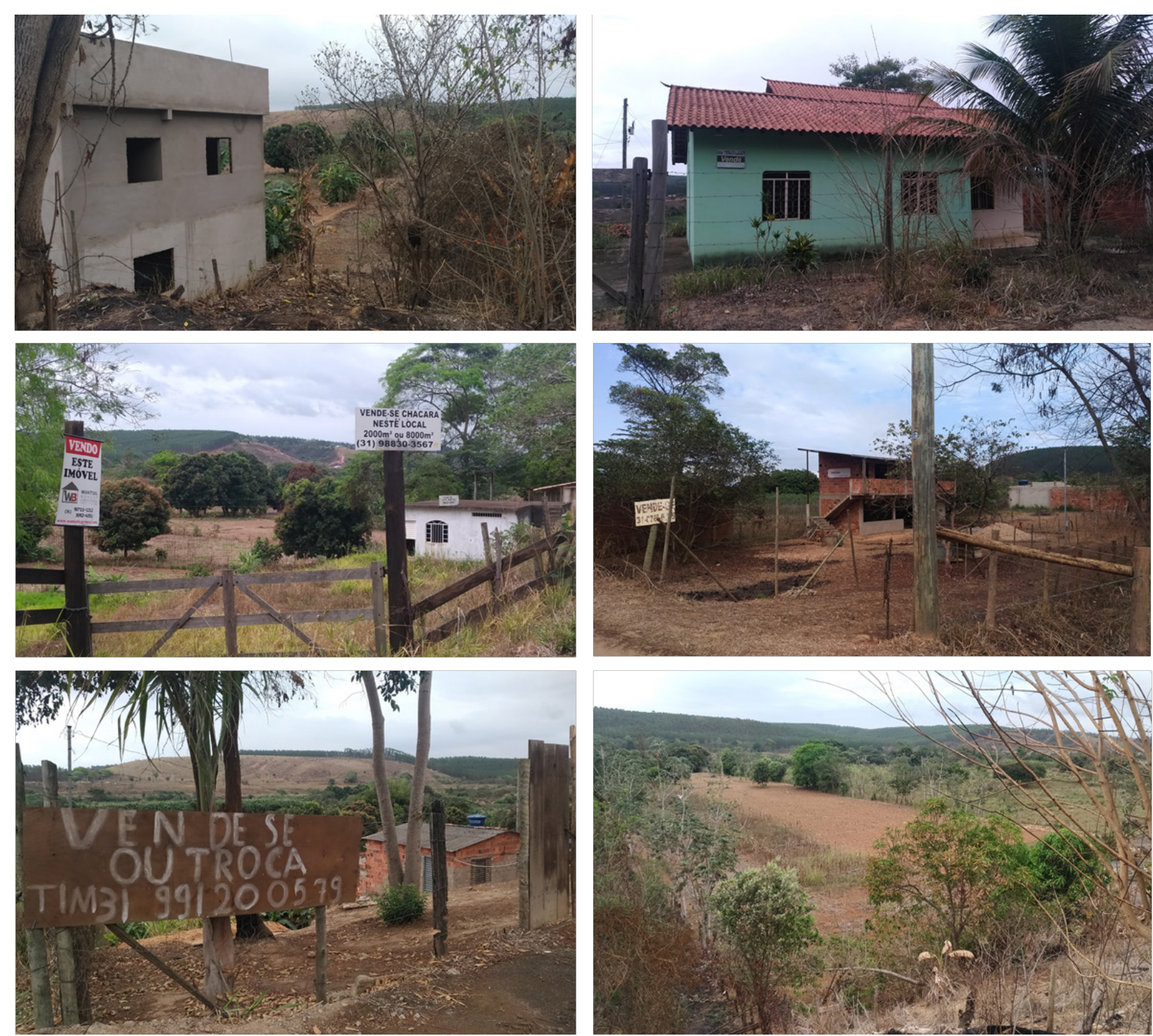

Figura 18 - Mosaico de imagens representando o processo de desterritorialização da Baixada Coronel Roberto. Propriedades, edificações abandonadas e placas de "vende-se" marcam a paisagem do local.

Fonte: Acervo da pesquisa, 2019. 

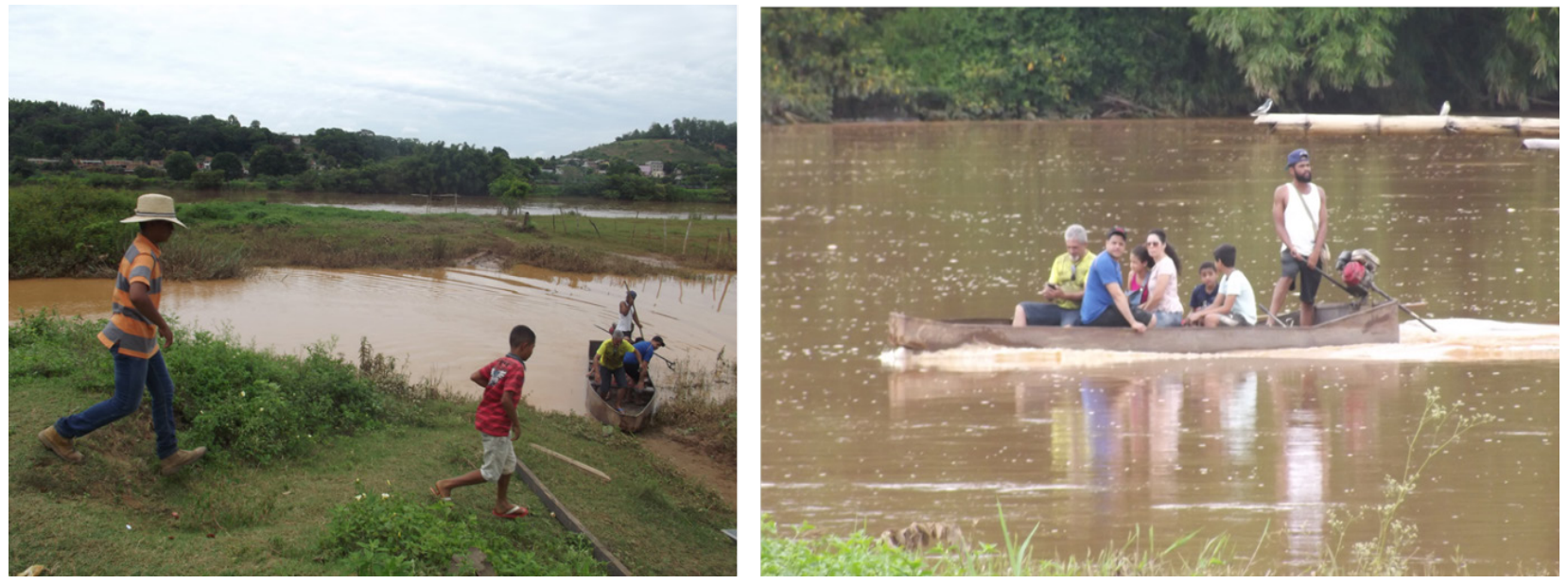

Figura 19 - Porto de botes de Ipaba.

Fonte: Acervo da pesquisa, 2019.

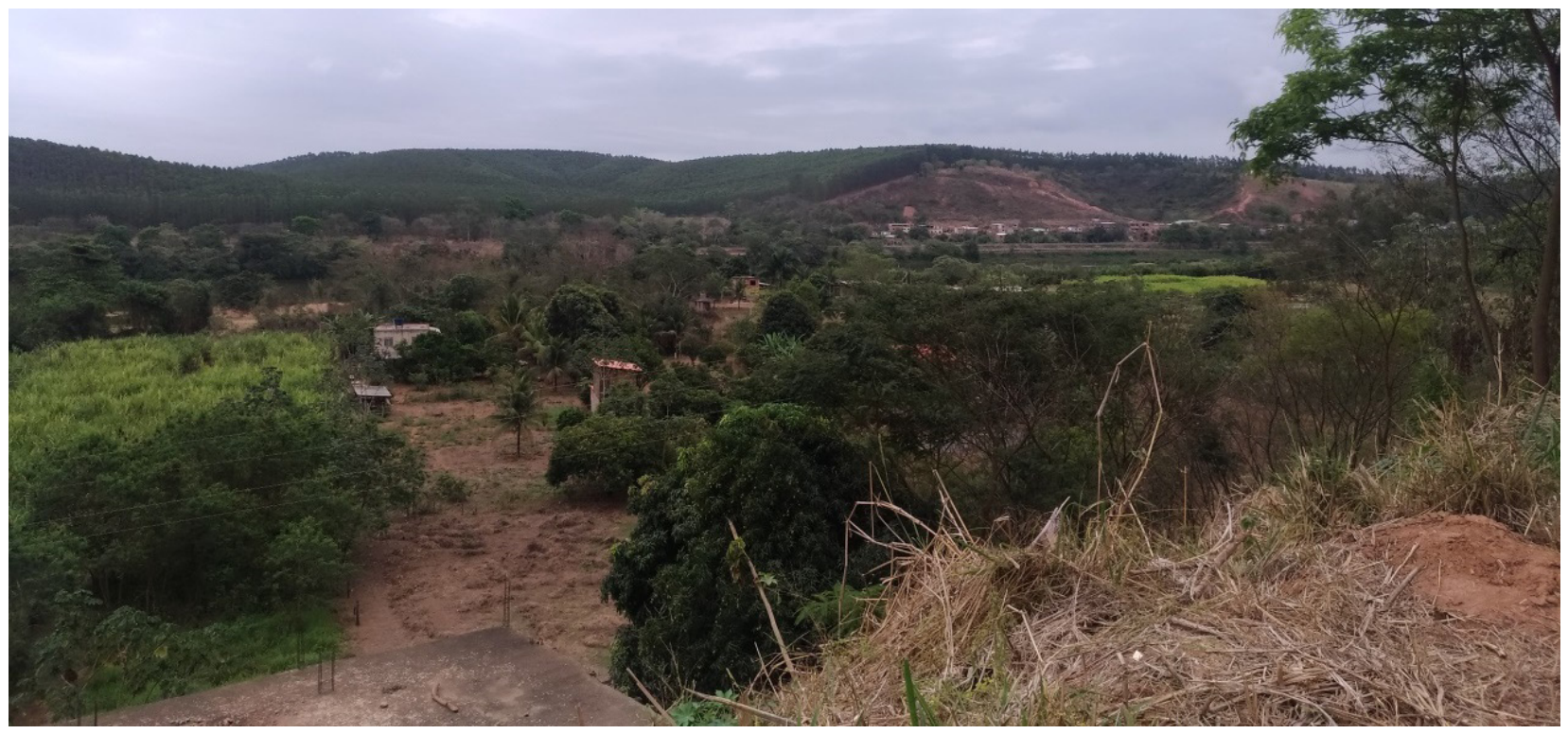

Figura 20 - Precariedade do tratamento das margens do rio Doce, em Ipaba. Fonte: Acervo da pesquisa, 2019. 
ao uso público no entorno do curso d'água, assim como de um tecido urbano que seja contíguo ao mesmo (Figura 20), se mostra como um ponto preocupante, visto que é por meio desses que são realizadas atividades cotidianas que possibilitam maior contato da população com o rio, e que dão ao curso d'água seu valor enquanto patrimônio socioambiental. O iminente cenário de crescimento urbano em sentido oposto ao rio pode reforçar a tendência de desvalorização de suas margens.

O Quadro 1, a seguir, sintetiza os resultados do estudo do espaço fluvial em Ipaba, segundo cada padrão de análise.

Quadro 1 - Síntese dos resultados da análise para Ipaba.

\begin{tabular}{|c|c|c|}
\hline 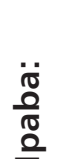 & $\begin{array}{c}\text { Tecidos - } \\
\text { permeabilidade do solo }\end{array}$ & $\begin{array}{l}\text { - Margem do rio Doce é predominantemente composta por áreas livres e permeáveis. } \\
\text { d'água. }\end{array}$ \\
\hline 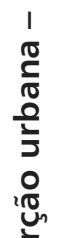 & $\begin{array}{c}\text { Tecidos - padrões de } \\
\text { urbanização }\end{array}$ & $\begin{array}{l}\text { - } \\
\text { - } \\
\text { - } \\
\text { - }\end{array}$ \\
\hline 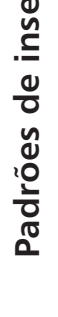 & $\begin{array}{l}\text { Assentamentos - } \\
\text { estrutura viária }\end{array}$ & $\begin{array}{l}\text { Rio com pouca acessibilidade física e visual na cidade. } \\
\text { - } \quad \text { Ausência de espaços livres de uso público e de equipamentos urbanos de qualidade às } \\
\text { margens do rio Doce. } \\
\text { - } \quad \text { Ausência de infraestruturas para transposição. } \\
\text { - } \quad \text { Lama de rejeitos da Samarco acentuou processos de degradação física e social das } \\
\text { margens do rio. }\end{array}$ \\
\hline
\end{tabular}

Fonte: Elaborado pelos autores.

\section{Considerações Finais}

Este trabalho teve o objetivo de analisar a relação entre espaço urbano e espaço fluvial no município de Ipaba, por meio de método desenvolvido por Souza (2015). Em Ipaba, foi visto que, a despeito de sua área urbana compacta e altamente impermeável, a maior parte das margens do rio Doce é ocupada por espaços permeáveis. Também foi observado que, apesar de a legislação contar com pa- râmetros de ocupação mais restritivos para áreas próximas ao rio, a mesma ainda é pouco detalhada e carece de parâmetros mais específicos para controle da ocupação do espaço fluvial.

O espaço fluvial na cidade é mais ruralizado, sendo ocupado por propriedades agrícolas, compostas por sítios e chácaras. Também é notória a presença de áreas destinadas ao plantio de eucalipto, que merecem atenção especial, devido aos impactos socioambientais 
que podem gerar. O plantio de eucalipto denota a ampla influência da indústria Cenibra na apropriação territorial do Vale do Aço, ditando, inclusive, a lógica de expansão de cidades. Ademais, o centro urbano de Ipaba pouco de relaciona com o rio, e os vetores de expansão identificados estão situados em sentido oposto às margens, ao longo de eixos rodoviários.

As margens do curso d'água, em Ipaba, estão predominantemente inseridas em fundos de propriedades agrícolas, prejudicando sua acessibilidade pública física e visual. $O$ rio é pouco notado na área urbana e somente pode ser visualizado em poucos pontos da cidade. O único ponto formal de acessibilidade física é o porto de botes, porém, tanto a área quanto o entorno não possuem tratamento urbanístico e paisagístico. Ressaltam-se os impactos da lama de rejeitos da barragem da Samarco, que ocasionaram a expropriação de moradores da Baixada Coronel Roberto, e reforçam a tendência de crescimento da cidade de modo a se distanciar fisicamente do rio.

24 O cenário de degradação do espaço fluvial observado em Ipaba é fruto de sua condição histórica de cidade-periferia (Arte/Cidade, 2004), em meio a uma região metropolitana extremamente dinâmica. O modelo de ocupação do Vale do Rio Doce, de cunho exclusivamente extrativista, resultou em quadros de desigualdade que reverberam nas relações entre cidades e rio. Observa-se que os impactos das atividades industriais ali desenvolvidas, a saber, mineração e produção de celulose, têm forte repercussão sobre o espaço fluvial e, somados à ausência de políticas públicas eficazes e a uma tendência de crescimento da cidade em sentido oposto ao rio, podem resultar em um cenário de distanciamento físico e afetivo, agravando o estado de precariedade atual. O aprimoramento da legislação municipal, assim como a criação de espaços mais dinâmicos e providos de infraestrutura que potencializem a função social das margens do rio Doce, entendendo-o como parte intrínseca do SEL urbano, podem ser um caminho para a reversão dessa tendência.

\section{Referências Bibliográficas}

ARTE/ CIDADE, Grupo de Intervenções Urbanas; PUC/SP; UFES/ ES. MG-ES: Um Sistema Infraestrutural, 2004. Disponível em: <http://www.pucsp.br/artecidade/mg_es/portugues/pesquisa.htm>. Acesso em: $27 \mathrm{de} \mathrm{fev.} \mathrm{de} 2020$.

BRASIL. Lei $n^{\circ} 6.766$, de 19 de dezembro de 1979. Dispõe sobre o Parcelamento do Solo Urbano e dá outras Providências. Diário Oficial da União. Brasília, 1979.

BRASIL. Lei $\mathrm{n}^{\circ} \mathbf{9 . 4 3 3}$, de 08 de janeiro de 1997. Institui a Política Nacional de Recursos Hídricos, cria o Sistema Nacional de Gerenciamento de Recursos Hídricos e dá outras providências. Diário Oficial da União. Brasília, 1997.

CELULOSE NIPO-BRASILEIRA S.A. (CENIBRA). Relatório de sustentabilidade 2018. Comunicação Corporativa e Relações Institucionais. Belo Horizonte, 2018.

COELHO, André Luiz Nascentes. Alterações Hidrogeomorfológicas no Médio-Baixo Rio Doce/ES. 2007. 227 f. Tese (Doutorado em Geografia) - Instituto de Geociências da Universidade Federal Fluminense, Niterói, 2007.

COELHO, André Luiz Nascentes. Bacia Hidrográfica do Rio Doce (MG/ES): uma análise socioambiental integrada. Revista GeografarES, Vitória - ES, n 7, 2009. P 131-146. DOI:https://doi.org/10.7147/GEO7.156

COELHO, André Luiz Nascentes. Mudanças históricas na morfologia fluvial no médio-baixo Rio Doce por processos de erosão e sedimentação. 1. ed. - Vitória, ES: UFES, Proex, 2019

COSTA, Geraldo Magela; COSTA, Heloísa Soares de Moura. Novas e velhas diferenças: desafios à gestão metropolitana no Vale do Aço. In: ENCONTRO NACIONAL DE ESTUDOS POPULACIONAIS, 12., 2000, Caxambu. Anais... Caxambu: ABEP, 2000.

COSTA, Heloisa Soares de Moura. Indústria, produção do espaço e custos socioambientais: reflexões a partir do exemplo do Vale do Aço, Minas Gerais. In: COSTA Haroldo; COSTA, Heloisa. População e meio ambiente: debates e desafios São Paulo: SENAC, 2000. p. 163-187.

COSTA, Lucia Maria Sá Costa (org.). Rios e Paisagens urbanas em cidades brasileiras. Rio de Janeiro: Viana et Mosleu: ed. PROURB, 2006.

CROCE, Rômulo. Relações entre espaço urbano e cursos d'água: conflitos e interações no Vale do Rio Doce. 2020. 378 f. Dissertação (Mestrado em Arquitetura e Urbanismo) - Programa de Pós-Graduação em Arquitetura e Urbanismo da Universidade Federal do Espírito Santo, Vitória, 2020.

CUNHA, Sandra Baptista da. Rios Desnaturalizados. In: BARBOSA, J. L. (Org.). Ordenamento Territorial e Ambiental. 1. ed. Niterói: Eduff, pp. 171-191, 2012.

FELIPPE, Miguel Fernandes; COSTA, Alfredo; JÚNIOR, Roberto Franco; MATOS, Ralfo Edmundo da Silva; JÚNIOR, Antônio Pereira Magalhães. Acabou-se o que era Doce: notas geográficas sobre a construção de um desastre ambiental. In: MILANEZ, Bruno: LOSEKANN, Cristiana, Desastre no vale do rio Doce: Antecedentes, impactos e ações sobre a destruição. Rio de Janeiro: Folio Digital: Letra e Imagem, 2016.

FERREIRA, Simone Raquel Batista. Marcas da colonialidade do poder no conflito entre a mineradora Samarco, os povos originários e comunidades tradicionais do Rio Doce. In: MILANEZ, Bruno; LOSEKANN, Cristiana, Desastre no vale do rio Doce: Antecedentes, impactos e ações sobre a destruição. Rio de Janeiro: Folio Digital: Letra e Imagem, 2016. 
FUNDAÇÃO JOÃO PINHEIRO - FJP, INSTITUTO DE PESQUISA ECONÔMICA APLICADA IPEA, PROGRAMA DAS NAÇOESS UNIDASPARA O DESENVOLVIMENTO - PNUD. Indice de desenvolvimento Humano dos Municípios Brasileiros - IDH-M. Disponível em: < https://cidades.ibge.gov.br/brasil/mg/ipaba/panorama>.

GORSKI, Maria Cecília Barbieri. Rios e cidades: ruptura e reconciliação. São Paulo: Senac, 2010.

INSTITUTO BRASILEIRO DE GEOgRAFIA E ESTATístICA (IBGE). Censo Demográfico de 2000. IBGE, 2000.

INSTITUTO BRASILEIRO DE GEOGRAFIA E ESTATÍSTICA (IBGE). População estimada 2018. IBGE, 2018.

INSTITUTO BRASILEIRO DE GEOGRAFIA E ESTATíSTICA (IBGE). População estimada 2019. IBGE, 2019.

INSTITUTO BRASILEIRO DE GEOGRAFIA E ESTATÍSTICA (IBGE). Produto interno bruto dos municípios. IBGE, 2016.

INSTITUTO BRASILEIRO DE GEOGRAFIA E ESTATíSTICA (IBGE). Regiões de Influência das Cidades. IBGE, 2008

IPABA. Lei $n^{\circ}$ 814/2019. Institui e aprova o plano de expansão do perímetro urbano do município de ipaba, nos termos do art. 42-b da lei federal $n^{\circ} 10.257 / 2001$. Ipaba, 2019.

MAGNOLI, Miranda. Ambiente, paisagem e espaço. Revista Paisagem e Ambiente. São Paulo: FAU-USP, n. 21. 2006. DOI: https://doi.org/10.11606/issn.2359-5361. v0i21 p237-244.

MELLO, Sandra Soares de. Na beira do rio tem uma cidade: urbanidade e valorização dos corpos d'água. Tese (Doutorado em Arquitetura e Urbanismo), Universidade de Brasília, Brasília, 2008.

PLANO INTEGRADO DE RECURSOS HÍDRICOS DA BACIA HIDROGRÁFICA DO RIO DOCE (PIRH). Relatório Executivo. Consórcio Ecoplan-Lume, 2010.

SILVA, Bárbara Oliveira. As margens dos cursos d'água de Patos de Minas: estudo da relação entre a configuração espacial e a qualidade ambiental urbana. Dissertação (Mestrado em Arquitetura e Urbanismo) - Universidade Federal de Uberlândia. Uberlândia, 2019.

SOUZA, Conrado Blanco. APPs fluviais urbanas e sistemas de espaços livres: uma análise da influência do código florestal na forma das cidades brasileiras. 2015. 165 f. Dissertação (Mestrado em Arquitetura e Urbanismo) - Faculdade de Arquitetura e Urbanismo da Universidade de São Paulo, São Paulo, 2015. DOI: 10.11606/D.16.2015. tde-09092015-103737.

WANDERLEY Luiz Jardim; MANSUR, Maíra Sertã; MILANEZ, Bruno; GIFFONI PINTO, Raquel. Desastre da Samarco/Vale/BHP no Vale do Rio Doce: aspectos econômicos, políticos e socio ambientais. Ciência e Cultura (Online), v. 68, n. 3, p. 30-35, 2016.

\section{Agradecimento}

"Os autores agradecem à Fundação de Amparo à Pesquisa e Inovação do Espírito Santo - FAPES, pelo auxílio financeiro (Processo $\left.\mathrm{n}^{\circ} 85010626\right)$ e bolsa de estudos, como subsídios à pesquisa, que resultou neste artigo."

\section{Rômulo Croce}

Universidade Federal do Espírito Santo (UFES), Programa de

Pós-Graduação em Arquitetura e Urbanismo da Universidade Federal

do Espírito Santo (PPGAU).

Av. Fernando Ferrari, 514 - Goiabeiras, Vitória - ES, CEP: 29075-910

https://orcid.org/0000-0001-7229-6398

romulocroce@gmail.com

\section{Eneida Maria Souza Mendonça}

Universidade Federal do Espírito Santo (UFES), Programa de

Pós-Graduação em Arquitetura e Urbanismo da Universidade Federal

do Espírito Santo (PPGAU)

Av. Fernando Ferrari, 514 - Goiabeiras, Vitória - ES, CEP: 29075-910

https://orcid.org/0000-0002-3290-2215

eneidamendonca@gmail.com

\section{Nota do Editor:}

Data de Submissão: 05/06/2020

Aprovação: 03/05/2021

Revisão: RMO 